\title{
Syntheses, Characterization, Thermal, and Antimicrobial Studies of Lanthanum(III) Tolyl/Benzyldithiocarbonates
}

\author{
Savit Andotra, Nidhi Kalgotra, and Sushil K. Pandey \\ Department of Chemistry, University of Jammu, Baba Saheb Ambedkar Road, Jammu 180 006, India \\ Correspondence should be addressed to Sushil K. Pandey; kpsushil@rediffmail.com
}

Received 29 October 2013; Accepted 3 January 2014; Published 9 April 2014

Academic Editor: Viktor Brabec

Copyright (C) 2014 Savit Andotra et al. This is an open access article distributed under the Creative Commons Attribution License, which permits unrestricted use, distribution, and reproduction in any medium, provided the original work is properly cited.

\begin{abstract}
Lanthanum(III) tris $\left(O\right.$-tolyl/benzyldithiocarbonates), $\left[\mathrm{La}\left(\mathrm{ROCS}_{2}\right)\right]\left(\mathrm{R}=o-, m-, p-\mathrm{CH}_{3} \mathrm{C}_{6} \mathrm{H}_{4}\right.$ and $\left.\mathrm{C}_{6} \mathrm{H}_{5} \mathrm{CH}_{2}\right)$, were isolated as yellow solid by the reaction of $\mathrm{LaCl}_{3} \cdot 7 \mathrm{H}_{2} \mathrm{O}$ with sodium salt of tolyl/benzyldithiocarbonates, $\mathrm{ROCS}_{2} \mathrm{Na}\left(\mathrm{R}=o-, m-, p-\mathrm{CH}_{3} \mathrm{C}_{6} \mathrm{H}_{4}\right.$ and $\mathrm{C}_{6} \mathrm{H}_{5} \mathrm{CH}_{2}$ ), in methanol under anhydrous conditions in 1:3 molar ratio. These complexes have formed adducts with nitrogen and phosphorus donor molecules by straightforward reaction of these complexes with donor ligands, which have the composition of the type $\left[\mathrm{La}\left(\mathrm{ROCS}_{2}\right)_{3} \cdot \mathrm{nL}\right.$ ] (where $\mathrm{n}=2, \mathrm{~L}=\mathrm{NC}_{5} \mathrm{H}_{5}$ or $\mathrm{P}\left(\mathrm{C}_{6} \mathrm{H}_{5}\right)_{3}$ and $\mathrm{n}=1, \mathrm{~L}=\mathrm{N}_{2} \mathrm{C}_{12} \mathrm{H}_{8}$ or $\mathrm{N}_{2} \mathrm{C}_{10} \mathrm{H}_{8}$ ). Elemental analyses, mass, IR, TGA, and heteronuclear NMR $\left({ }^{1} \mathrm{H},{ }^{13} \mathrm{C}\right.$ and $\left.{ }^{31} \mathrm{P}\right)$ spectroscopic studies indicated bidentate mode of bonding by dithiocarbonate ligands leading to hexacoordinated and octacoordinated geometry around the lanthanum atom. Antimicrobial (antifungal and antibacterial) activity of the free ligands and some of the complexes have also been investigated which exhibited significantly more activity for the complexes than the free ligands.
\end{abstract}

\section{Introduction}

Alkyldithiocarbonates, more commonly referred to as xanthates, were first prepared by Semeniuc et al. [1]. Their applications as vulcanizers [2], fungicides [3], and flotation agents $[4,5]$ in metallurgy have been described in the literature. The synthetic and structural chemistry of xanthates witnessed increased attention through the pioneering work of Winter [6], Tiekink and Winter [7], Hoskins and Pannan [8], and Dakternieks et al. [9]. Subsequently, extensive structural analyses were performed by Tiekink and Haiduc [10], which showed that these ligands can coordinate to metal atoms in a monodentate, isobidentate, or anisobidentate fashion. More recent applications of xanthates and other thio compounds are in the production of nanoparticles of metal sulphides $[11,12]$ and NLO properties $[13,14]$. Metal xanthates are extensively used as pesticides [15], corrosion inhibitors [16], agricultural reagents [17], and quite recently in therapy for HIV infections [18]. Moreover, xanthates are also known to show antitumor properties $[19,20]$ and their antioxidant properties could be of importance for treating Alzheimer's disease [21]. These have extensively been used as intermediates in organic synthesis, in free radical polymerization, for rechargeable lithium ion batteries, and so forth $[22,23]$. Sodium and potassium ethyl xanthate have antidotal effects on acute mercurial poisoning [24]. Much progress has recently been achieved in the coordination chemistry of lanthanides [25]. The design and synthesis of lanthanide(III) complexes with chelating ligands have many potential applications such as light-emitting devices, sensors, liquid crystalline materials, and chelate lasers [26]. Both lanthanum and xanthate find their applications in the field of medicinal chemistry [27, 28]. In spite of years of chemistry of the extensive and long term use of alkyl xanthates as ligands [29-35], structural and spectroscopic characterization have been rather limited with regard to the aryl xanthates [36, 37]. Fackler et al., however, reported the synthesis of thallium aryl xanthates which are in turn used for the metathetical synthesis of other metal derivatives [36]. We report herein for the first time the synthesis and characterization of $O$-tolyl/benzyl xanthates of lanthanum(III) and their adducts with nitrogen and phosphorus donor ligands like pyridine $\left(\mathrm{NC}_{5} \mathrm{H}_{5}\right)$, triphenylphosphine $\left[\mathrm{P}\left(\mathrm{C}_{6} \mathrm{H}_{5}\right)_{3}\right], 1,10$-phenanthroline $\left(\mathrm{N}_{2} \mathrm{C}_{12} \mathrm{H}_{8}\right)$, and 2,2' -bipyridyl $\left(\mathrm{N}_{2} \mathrm{C}_{10} \mathrm{H}_{8}\right)$. 


\section{Experimental}

2.1. Materials and Methods. Stringent precautions were taken to exclude moisture during the preparation of ligands. Moisture was carefully excluded throughout the experimental manipulations by using standard Schlenk techniques. Sodium salts of dithiocarbonates were obtained using literature procedures [2]. Toluene (Thomas Baker, B.P. $110^{\circ} \mathrm{C}$ ) and $n$-hexane (Thomas Baker, B.P. 68-69 ${ }^{\circ} \mathrm{C}$ ) were freshly dried over sodium wire. Methanol (Thomas Baker, B.P. $64^{\circ} \mathrm{C}$ ) was dried over $\mathrm{P}_{2} \mathrm{O}_{5}$ and $\mathrm{CaCO}_{3}$, respectively. Cresols (ortho-, meta-, and para-) and benzyl alcohol (Thomas Baker, B.P. $191^{\circ} \mathrm{C}, 203^{\circ} \mathrm{C}$, $202^{\circ} \mathrm{C}$, and $205^{\circ} \mathrm{C}$ ) were purified by distillation prior to use.

2.2. Physical Measurements. Lanthanum was estimated gravimetrically as lanthanum oxide [38]. Elemental analyses (C, $\mathrm{H}, \mathrm{N}$, and S) were carried out on CHNS-932 Leco Elemental analyzer and ESI mass spectra of the compounds were recorded on ESQUIRE 3000-00037 spectrophotometer from Indian Institute of Integrative Medicine (IIIM), Jammu. The IR spectra were recorded in $\mathrm{KBr}$ pallets in the range of $4000-200 \mathrm{~cm}^{-1}$ on a Perkin Elmer spectrum RX1-FT IR spectrophotometer and multinuclear $\left({ }^{1} \mathrm{H},{ }^{13} \mathrm{C}\right.$, and $\left.{ }^{31} \mathrm{P}\right) \mathrm{NMR}$ spectra were recorded in $\mathrm{CDCl}_{3}$ on a Brucker Avance II $400 \mathrm{MHz}$ spectrometer using TMS as internal reference for ${ }^{1} \mathrm{H}$ and ${ }^{13} \mathrm{C}$ and $85 \% \mathrm{H}_{3} \mathrm{PO}_{4}$ as external reference for ${ }^{31} \mathrm{P}$ NMR at Sophisticated Analytical Instrumentation Facility (SAIF), Punjab University, Chandigarh. The thermogram was analyzed by using Perkin Elmer, diamond TG/DTA instrument. The thermogram was recorded in the temperature range from $30^{\circ} \mathrm{C}$ to $1000^{\circ} \mathrm{C}$ under nitrogen atmosphere from National Chemical Lab (NCL), Pune. Also the antifungal and antibacterial activity were tested under laboratory condition in the Bioassay Lab, Department of Chemistry, University of Jammu, Jammu, using classical poison food technique and agar well diffusion method.

\subsection{Synthetic Procedures}

2.3.1. Synthesis of $\left[\mathrm{La}\left(\mathrm{o}-\mathrm{CH}_{3} \mathrm{C}_{6} \mathrm{H}_{4} \mathrm{OCS}_{2}\right)_{3}\right]$ (5). A methanolic solution $(\sim 35 \mathrm{~mL})$ of sodium $\mathrm{O}$-(o-tolyl) dithiocarbonate $(1.00 \mathrm{~g}, 4.84 \mathrm{mmol})$ was added to methanolic solution of lanthanum chloride $(0.60 \mathrm{~g}, 1.61 \mathrm{mmol})$ with constant stiring at room temperature. Subsequently, the contents were refluxed for eight hours. The turbidity created by the byproduct (sodium chloride) was filtered off using alkoxy funnel fitted with G-4 sintered disc and volatiles were removed from the filtrate under reduced pressure. The solid thus obtained was extracted with chloroform $\left(\sim 20 \mathrm{~cm}^{3}\right)$ by stirring overnight. Again the insoluble's were filtered off and the desired product $\left[\mathrm{La}\left(o-\mathrm{CH}_{3} \mathrm{C}_{6} \mathrm{H}_{4} \mathrm{OCS}_{2}\right)_{3}\right](5)$ was obtained from the filtrate as yellow solid.

The compounds $\mathbf{6}-\mathbf{8}$ reported herein were synthesized by using similar methodology and required stoichiometric weights. The relevant synthetic and analytical data are given in Table 1.
2.3.2. Synthesis of $\left[\mathrm{La}\left(\mathrm{o}-\mathrm{CH}_{3} \mathrm{C}_{6} \mathrm{H}_{4} \mathrm{OCS}_{2}\right)_{3} \cdot 2 \mathrm{NC}_{5} \mathrm{H}_{5}\right]$ (9). Pyridine $(0.11 \mathrm{~g}, 1.39 \mathrm{mmol})$ was added with constant stirring to a methanolic $(\sim 15 \mathrm{~mL})$ solution of $\left[\mathrm{La}\left(o-\mathrm{CH}_{3} \mathrm{C}_{6} \mathrm{H}_{4} \mathrm{OCS}_{2}\right)_{3}\right]$ $(0.50 \mathrm{~g}, 0.72 \mathrm{mmol})$. The mixture was refluxed for two hours. The solvent was evaporated in vacuo and the product was washed with dry $n$-hexane for the sake of purity and finally dried under reduced pressure that resulted in the formation of the compound $\left[\mathrm{La}\left(\mathrm{o}-\mathrm{CH}_{3} \mathrm{C}_{6} \mathrm{H}_{4} \mathrm{OCS}_{2}\right)_{3} \cdot 2 \mathrm{NC}_{5} \mathrm{H}_{5}\right](9)$ in $89 \%$ yield.

The compounds $\mathbf{1 0} \mathbf{- 2 4}$ reported herein were synthesized by using similar methodology and required stoichiometric weights. The relevant synthetic and analytical data are given in Table 1.

\subsection{Antimicrobial Activity}

2.4.1. Antifungal Activity. Potato dextrose medium (PDA) was prepared in a flask and sterilized. Now, $100 \mu \mathrm{L}$ of each sample was added to the PDA medium and poured into each sterilized petri plate. Mycelial discs taken from the standard culture (Fusarium oxysporum) of fungi were grown on PDA medium for 7 days. These cultures were used for aseptic inoculation in the sterilized petri dish. Standard cultures, inoculated at $28 \pm 1^{\circ} \mathrm{C}$, were used as the control. The efficiency of each sample was determined by measuring the radial fungal growth. The radial growth of the colony was measured in two directions at right angles to each other and the average of two replicates was recorded in each case. Data were expressed as percent inhibition over the control from the size of the colonies. The percent inhibition was calculated using the formula \% Inhibition $=((C-T) / C) \times 100$, where $C$ is the diameter of the fungus colony in the control plate after 96 hour incubation and $T$ is the diameter of the fungus colony in the tested plate after the same incubation period.

2.4.2. Antibacterial Activity. Test samples were prepared in different concentrations $(250,500$, and 1000 ppm) in DMSO. Agar medium $(20 \mathrm{~mL})$ was poured into each petri plate. The plates were swabbed with broth cultures of the respective microorganisms Klebsiella pneumonia and Bacillus cereus and kept for 15 minutes for adsorption to take place. About $6 \mathrm{~mm}$ diameter holes were created in the seeded agar plates using a punch and $100 \mu \mathrm{L}$ of the DMSO solution of each test compound was poured into the wells. DMSO was used as the control for all the test compounds. After holding the plates at room temperature for $2 \mathrm{hrs}$ to allow diffusion of the compounds into the agar then the plates were incubated at $37^{\circ} \mathrm{C}$ for $24 \mathrm{hrs}$. The antibacterial activity was determined by measuring the diameter of the inhibition zone. The entire tests were made in triplicates and the mean of the diameter of inhibition was calculated.

\section{Results and Discussion}

Reactions of lanthanum trichloride, $\mathrm{LaCl}_{3} \cdot 7 \mathrm{H}_{2} \mathrm{O}$, with sodium salt of $(o-, m$-, and $p$-tolyl/benzyl)dithiocarbonates, (o-, $m$-, and $\left.p-\mathrm{CH}_{3} \mathrm{C}_{6} \mathrm{H}_{4} \mathrm{OCS}_{2}\right) \mathrm{Na} /\left(\mathrm{C}_{6} \mathrm{H}_{5} \mathrm{CH}_{2} \mathrm{OCS}_{2}\right) \mathrm{Na}(\mathbf{1}-\mathbf{4})$, in 1:3 molar ratio were carried out in methanol which 


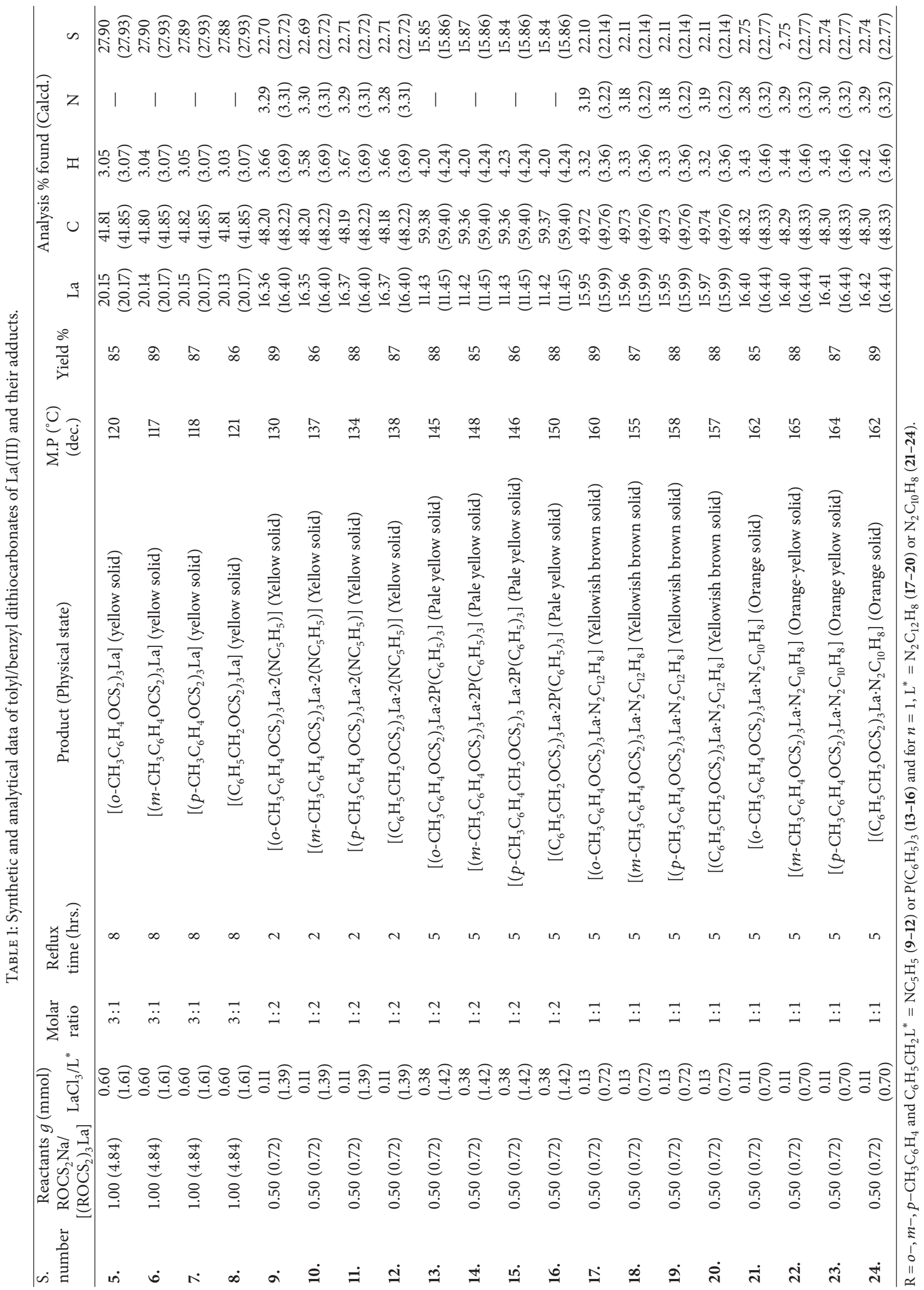


TABLE 2: Mass spectral data of tolyl/benzyl dithiocarbonates of La(III) and their adducts.

\begin{tabular}{|c|c|c|}
\hline S. No. ${ }^{*}$ & M.W. & $m / z$, Relative intensities of the ions and assignment \\
\hline 5. & 688 & $\begin{array}{l}{\left[\mathrm{M}^{+}\right] 688(11)\left[\mathrm{La}\left(o-\mathrm{CH}_{3} \mathrm{C}_{6} \mathrm{H}_{4} \mathrm{OCS}_{2}\right)_{3}\right] ;\left[\mathrm{M}^{+}\right] 183(30)\left[o-\mathrm{CH}_{3} \mathrm{C}_{6} \mathrm{H}_{4} \mathrm{OCS}_{2}\right] ;\left[\mathrm{M}^{+}\right] 107(18)} \\
{\left[o-\mathrm{CH}_{3} \mathrm{C}_{6} \mathrm{H}_{4} \mathrm{O}\right] ;} \\
{\left[\mathrm{M}^{+}\right] 504(15)\left[\mathrm{La}\left(o-\mathrm{CH}_{3} \mathrm{C}_{6} \mathrm{H}_{4} \mathrm{OCS}_{2}\right)_{2}\right] ;\left[\mathrm{M}^{+}\right] 321(7)\left[\mathrm{La}\left(o-\mathrm{CH}_{3} \mathrm{C}_{6} \mathrm{H}_{4} \mathrm{OCS}_{2}\right)\right] ;\left[\mathrm{M}^{+}\right] 503(15)} \\
{\left[\left(\mathrm{C}_{6} \mathrm{H}_{4} \mathrm{OCS}_{2}\right)_{3}\right] ;} \\
{\left[\mathrm{M}^{+}\right] 474(9)\left[\mathrm{La}\left(\mathrm{C}_{6} \mathrm{H}_{4} \mathrm{OCS}_{2}\right)_{2}\right] ;\left[\mathrm{M}^{+}\right] 306(10)\left[\mathrm{La}\left(\mathrm{C}_{6} \mathrm{H}_{4} \mathrm{OCS}_{2}\right)\right] ;\left[\mathrm{M}^{+}\right] 168(8)\left[\left(\mathrm{C}_{6} \mathrm{H}_{4} \mathrm{OCS}_{2}\right)\right]}\end{array}$ \\
\hline 9. & 846 & $\begin{array}{l}{\left[\mathrm{M}^{-}\right] 846(7)\left[\mathrm{La}\left(o-\mathrm{CH}_{3} \mathrm{C}_{6} \mathrm{H}_{4} \mathrm{OCS}_{2}\right)_{3} \mathrm{La} \cdot 2 \mathrm{NC}_{5} \mathrm{H}_{5}\right] ;\left[\mathrm{M}^{+}\right] 687(15)\left[\mathrm{La}\left(o-\mathrm{CH}_{3} \mathrm{C}_{6} \mathrm{H}_{4} \mathrm{OCS}_{2}\right)_{3}\right] ;\left[\mathrm{M}^{-}\right]} \\
183(15) \\
{\left[\left(o-\mathrm{CH}_{3} \mathrm{C}_{6} \mathrm{H}_{4} \mathrm{OCS}_{2}\right)\right] ;\left[\mathrm{M}^{-}\right] 107(16)\left[o-\mathrm{CH}_{3} \mathrm{C}_{6} \mathrm{H}_{4} \mathrm{O}\right] ;\left[\mathrm{M}^{+}\right] 662(15)} \\
{\left[\mathrm{La}\left(o-\mathrm{CH}_{3} \mathrm{C}_{6} \mathrm{H}_{4} \mathrm{OCS}_{2}\right)_{2} \cdot 2 \mathrm{NC}_{5} \mathrm{H}_{5}\right] ;} \\
{\left[\mathrm{M}^{+}\right] 296(12)\left[\mathrm{La} \cdot 2 \mathrm{NC}_{5} \mathrm{H}_{5}\right] .}\end{array}$ \\
\hline 14. & 1213 & $\begin{array}{l}{\left[\mathrm{M}^{+}\right] 1213(5)\left[\mathrm{La}\left(m-\mathrm{CH}_{3} \mathrm{C}_{6} \mathrm{H}_{4} \mathrm{OCS}_{2}\right)_{3} \cdot 2 \mathrm{P}\left(\mathrm{C}_{6} \mathrm{H}_{5}\right)_{3}\right] ;\left[\mathrm{M}^{+}\right] 949(6)} \\
{\left[\mathrm{La}\left(m-\mathrm{CH}_{3} \mathrm{C}_{6} \mathrm{H}_{4} \mathrm{OCS}_{2}\right)_{3} \cdot \mathrm{P}\left(\mathrm{C}_{6} \mathrm{H}_{5}\right)_{3}\right] ;} \\
{\left[\mathrm{M}^{+}\right] 687(4)\left[\mathrm{La}\left(m-\mathrm{CH}_{3} \mathrm{C}_{6} \mathrm{H}_{4} \mathrm{OCS}_{2}\right)_{3}\right] ;\left[\mathrm{M}^{+}\right] 1029(9)\left[\mathrm{La}\left(m-\mathrm{CH}_{3} \mathrm{C}_{6} \mathrm{H}_{4} \mathrm{OCS}_{2}\right)_{2} \cdot 2 \mathrm{P}\left(\mathrm{C}_{6} \mathrm{H}_{5}\right)_{3}\right] ;} \\
{\left[\mathrm{M}^{+}\right] 504(6)\left[\mathrm{La}\left(m-\mathrm{CH}_{3} \mathrm{C}_{6} \mathrm{H}_{4} \mathrm{OCS}_{2}\right)_{2}\right] ;\left[\mathrm{M}^{+}\right] 183(7)\left[m-\mathrm{CH}_{3} \mathrm{C}_{6} \mathrm{H}_{4} \mathrm{OCS}_{2}\right] ;\left[\mathrm{M}^{-}\right] 107(7)} \\
{\left[m-\mathrm{CH}_{3} \mathrm{C}_{6} \mathrm{H}_{4} \mathrm{O}\right] .}\end{array}$ \\
\hline 19. & 868 & $\begin{array}{l}{\left[\mathrm{M}^{+}\right] 868(6)\left[\mathrm{La}\left(p-\mathrm{CH}_{3} \mathrm{C}_{6} \mathrm{H}_{4} \mathrm{OCS}_{2}\right)_{3} \cdot \mathrm{N}_{2} \mathrm{C}_{12} \mathrm{H}_{8}\right] ;\left[\mathrm{M}^{+}\right] 687(8)\left[\mathrm{La}\left(p-\mathrm{CH}_{3} \mathrm{C}_{6} \mathrm{H}_{4} \mathrm{OCS}_{2}\right)_{3}\right]} \\
{\left[\mathrm{M}^{+}\right] 684(7)\left[\mathrm{La}\left(p-\mathrm{CH}_{3} \mathrm{C}_{6} \mathrm{H}_{4} \mathrm{OCS}_{2}\right)_{2} \cdot \mathrm{N}_{2} \mathrm{C}_{12} \mathrm{H}_{8}\right] ;\left[\mathrm{M}^{+}\right] 321(4)\left[\mathrm{La}\left(p-\mathrm{CH}_{3} \mathrm{C}_{6} \mathrm{H}_{4} \mathrm{OCS}_{2}\right)\right]} \\
{\left[\mathrm{M}^{-}\right] 107(6)\left[p-\mathrm{CH}_{3} \mathrm{C}_{6} \mathrm{H}_{4} \mathrm{O}\right] ;\left[\mathrm{M}^{+}\right] 318(5)\left[\mathrm{La} \cdot \mathrm{N}_{2} \mathrm{C}_{12} \mathrm{H}_{8}\right] ;\left[\mathrm{M}^{+}\right] 180(5)\left[\mathrm{N}_{2} \mathrm{C}_{12} \mathrm{H}_{8}\right] ;}\end{array}$ \\
\hline 22. & 844 & $\begin{array}{l}{\left[\mathrm{M}^{+}\right] 844(6)\left[\mathrm{La}\left(m-\mathrm{CH}_{3} \mathrm{C}_{6} \mathrm{H}_{4} \mathrm{OCS}_{2}\right)_{3} \cdot \mathrm{N}_{2} \mathrm{C}_{10} \mathrm{H}_{8}\right] ;\left[\mathrm{M}^{+}\right] 687(8)\left[\mathrm{La}\left(m-\mathrm{CH}_{3} \mathrm{C}_{6} \mathrm{H}_{4} \mathrm{OCS}_{2}\right)_{3}\right]} \\
{\left[\mathrm{M}^{+}\right] 687(8)\left[\mathrm{La}\left(m-\mathrm{CH}_{3} \mathrm{C}_{6} \mathrm{H}_{4} \mathrm{OCS}_{2}\right)_{2}\right] ;\left[\mathrm{M}^{+}\right] 183(5)\left[o-\mathrm{CH}_{3} \mathrm{C}_{6} \mathrm{H}_{4} \mathrm{OCS}_{2}\right] ;} \\
{\left[\mathrm{M}^{-}\right] 477(6)\left[\mathrm{La}\left(m-\mathrm{CH}_{3} \mathrm{C}_{6} \mathrm{H}_{4} \mathrm{OCS}_{2}\right) \cdot \mathrm{N}_{2} \mathrm{C}_{10} \mathrm{H}_{8}\right] ;\left[\mathrm{M}^{+}\right] 294(4)\left[\mathrm{La}_{2} \mathrm{~N}_{2} \mathrm{C}_{10} \mathrm{H}_{8}\right] ;\left[\mathrm{M}^{+}\right] 156(20)} \\
{\left[\mathrm{N}_{2} \mathrm{C}_{10} \mathrm{H}_{8}\right]}\end{array}$ \\
\hline 24. & 844 & $\begin{array}{l}{\left[\mathrm{M}^{+}\right] 844(10)\left[\mathrm{La}\left(\mathrm{C}_{6} \mathrm{H}_{5} \mathrm{CH}_{2} \mathrm{OCS}_{2}\right)_{3} \cdot \mathrm{N}_{2} \mathrm{C}_{10} \mathrm{H}_{8}\right] ;\left[\mathrm{M}^{+}\right] 687(6)\left[\mathrm{La}\left(\mathrm{C}_{6} \mathrm{H}_{5} \mathrm{CH}_{2} \mathrm{OCS}_{2}\right)_{3}\right]} \\
\left.\left[\mathrm{M}^{+}\right] 613(4)\left[\mathrm{La}\left(\mathrm{CH}_{2} \mathrm{OCS}_{2}\right)_{3} \cdot \mathrm{N}_{2} \mathrm{C}_{10} \mathrm{H}_{8}\right)\right]\left[\mathrm{M}^{+}\right] 456(13)\left[\mathrm{La}\left(\mathrm{CH}_{2} \mathrm{OCS}_{2}\right)_{3}\right] ;\left[\mathrm{M}^{+}\right] 294(6) \\
{\left[\mathrm{La} \cdot \mathrm{N}_{2} \mathrm{C}_{10} \mathrm{H}_{8}\right] ;} \\
{\left[\mathrm{M}^{+}\right] 156(14)\left[\mathrm{N}_{2} \mathrm{C}_{10} \mathrm{H}_{8}\right]}\end{array}$ \\
\hline
\end{tabular}

Bracket $=m / z$; parentheses $=$ intensities in $\% ;{ }^{*}$ S. number of the complexes is according to Table 1.

resulted in the formation of complexes $\left[\mathrm{La}\left(\mathrm{ROCS}_{2}\right)_{3}\right]\left(\mathrm{R}=o^{-}\right.$, $m-, p-\mathrm{CH}_{3} \mathrm{C}_{6} \mathrm{H}_{4}$ and $\left.\mathrm{C}_{6} \mathrm{H}_{5} \mathrm{CH}_{2}\right)(5-8)$ as yellow solid in 85$89 \%$ yield (1). Reactions of $\left[\left(\mathrm{ROCS}_{2}\right) \mathrm{Na}\right]$ with $\mathrm{LaCl}_{3} \cdot 7 \mathrm{H}_{2} \mathrm{O}$ :

$$
\begin{gathered}
\underset{(1-4)}{3 \mathrm{ROCS}_{2} \mathrm{Na}}+\mathrm{LaCl}_{3} \cdot 7 \mathrm{H}_{2} \mathrm{O} \underset{-3 \mathrm{NaCl}, \operatorname{Reflux}}{\stackrel{\mathrm{CH}_{3} \mathrm{OH}}{\longrightarrow}}\left[\mathrm{La}\left(\mathrm{ROCS}_{2}\right)_{3}\right] \\
\left(\mathrm{R}=\mathbf{o}^{-}, m^{-}, \quad, p-\mathrm{CH}_{3} \mathrm{C}_{6} \mathrm{H}_{4} \text { and } \mathrm{C}_{6} \mathrm{H}_{5} \mathrm{CH}_{2}\right)
\end{gathered}
$$

The compounds of the type $\left[\mathrm{La}\left(\mathrm{ROCS}_{2}\right)_{3} \cdot \mathrm{nL}\right](\mathbf{8}-\mathbf{2 4})$ (where $\mathrm{n}=2, \mathrm{~L}=\mathrm{NC}_{5} \mathrm{H}_{5}(\mathbf{9}-12)$ or $\mathrm{P}\left(\mathrm{C}_{6} \mathrm{H}_{5}\right)_{3}(\mathbf{1 3}-\mathbf{1 6})$ and $\mathrm{n}=1, \mathrm{~L}=\mathrm{N}_{2} \mathrm{C}_{12} \mathrm{H}_{8}(\mathbf{1 7 - 2 0})$ or $\mathrm{N}_{2} \mathrm{C}_{10} \mathrm{H}_{8}$ (21-24)) were synthesized by the addition reactions of lanthanum(III) tris( $O$ tolyl/benzyl dithiocarbonates) with nitrogen and phosphorus donor ligands in $1: 2$ or $1: 1$ molar ratio in methanol (2). The formation of these donor stabilized compounds indicates that tris-lanthanum complexes are lewis acids. These reactions were quite facile. Reactions of $\left[\mathrm{La}\left(\mathrm{ROCS}_{2}\right)_{3}\right]$ with $\mathrm{N}$ and $\mathrm{P}$ donor ligands $\left(\mathrm{n}=2, \mathrm{~L}=\mathrm{NC}_{5} \mathrm{H}_{5}(\mathbf{9 - 1 2})\right.$ or $\mathrm{P}\left(\mathrm{C}_{6} \mathrm{H}_{5}\right)_{3}(\mathbf{1 3}-\mathbf{1 6})$ and $\mathrm{n}=1, \mathrm{~L}=\mathrm{N}_{2} \mathrm{C}_{12} \mathrm{H}_{8}(\mathbf{1 7}-\mathbf{2 0})$ or $\mathrm{N}_{2} \mathrm{C}_{10} \mathrm{H}_{8}$ (21-24)):

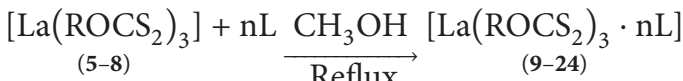

$$
\begin{aligned}
& \left(\mathrm{R}=o^{-}, m-, p-\mathrm{CH}_{3} \mathrm{C}_{6} \mathrm{H}_{4} \text { and } \mathrm{C}_{6} \mathrm{H}_{5} \mathrm{CH}_{2}\right)
\end{aligned}
$$

These compounds are soluble in ethanol, acetone, chloroform, and dichloromethane and insoluble in most hydrocarbon solvents. These compounds appear to be bit moisture sensitive; however, these can be kept unchanged under anhydrous atmosphere. These compounds are nonvolatile even under the reduced pressure and tend to decompose on heating. However, decomposition products could not be identified. The synthetic and analytical data are given in Table 1.

\subsection{Spectroscopic Studies}

3.1.1. Mass Spectra. The mass spectra of a few representative lanthanum(III) complexes and their adducts $(5,9,14,19$, 22, and 24) have shown their molecular ion peak $\left[\mathrm{M}^{+}\right]$at $m / z=688,846,1213,868,844$, and 844 , respectively. The value of molecular ion peak $[\mathrm{M}]^{+}$in these complexes is an indicative of monomeric nature. Some other peaks were also observed which corresponds to the fragmented species after the successive removal of different groups. Based on the presence of the peaks in the mass spectra of some of the representative complexes, the various fragments have been given in Table 2.

3.1.2. IR Spectra. The characteristic stretching bands in the IR spectra (4000-200) $\mathrm{cm}^{-1}$ were assigned by comparison with literature data $[2,14,39,40]$. The IR spectra of these complexes exhibited band in the region $1260-1238 \mathrm{~cm}^{-1}$ for $v(\mathrm{C}-\mathrm{O}-\mathrm{C})$. The bands observed in the region 3059-3012 and $1601-1560 \mathrm{~cm}^{-1}$ were ascribed to ring vibrations in the cyclic dithiocarbonates. The presence of one strong band for $v(\mathrm{C}-\mathrm{S})$ 
TABLE 3: IR spectral data of tolyl/benzyl dithiocarbonates of $\mathrm{La}(\mathrm{III})$ and their adducts $\left(\mathrm{cm}^{-1}\right)$.

\begin{tabular}{|c|c|c|c|c|c|c|}
\hline \multirow{2}{*}{ S. number* } & \multirow{2}{*}{$v \mathrm{C}-\mathrm{O}-\mathrm{C}$} & \multirow{2}{*}{$v \mathrm{C}-\mathrm{S}$} & \multicolumn{2}{|c|}{ Aromatic stretching } & \multirow{2}{*}{$v \mathrm{La}-\mathrm{S}$} & \multirow{2}{*}{$v \mathrm{La}-\mathrm{N} / \mathrm{La}-\mathrm{P}^{* *}$} \\
\hline & & & $v \mathrm{C}-\mathrm{H}$ & $v \mathrm{C}-\mathrm{C}$ & & \\
\hline 5. & $1248, \mathrm{~s}$ & $1039, \mathrm{~m}$ & $3018, \mathrm{~b}$ & $1599, \mathrm{~s}$ & $312, \mathrm{w}$ & - \\
\hline 6. & $1249, s$ & $1036, \mathrm{~m}$ & $3012, \mathrm{~b}$ & $1595, \mathrm{~s}$ & $320, w$ & - \\
\hline 7. & $1248, s$ & $1038, \mathrm{~m}$ & $3028, \mathrm{~b}$ & $1596, \mathrm{~s}$ & $325, w$ & - \\
\hline 8. & $1238, \mathrm{~s}$ & $1037, \mathrm{~m}$ & $3029, \mathrm{~b}$ & $1594, s$ & $310, \mathrm{w}$ & - \\
\hline 9. & $1239, \mathrm{~s}$ & $1039, \mathrm{~m}$ & $3030, \mathrm{~b}$ & $1595, \mathrm{~s}$ & $330, w$ & $450, \mathrm{w}$ \\
\hline 10. & $1245, \mathrm{~s}$ & $1035, \mathrm{~m}$ & $3055, \mathrm{~b}$ & $1598, s$ & $324, w$ & $455, \mathrm{w}$ \\
\hline 11. & $1239, \mathrm{~s}$ & $1040, \mathrm{~m}$ & $3047, \mathrm{~b}$ & $1597, \mathrm{~s}$ & $320, w$ & $445, \mathrm{w}$ \\
\hline 12. & $1247, \mathrm{~s}$ & $1034, \mathrm{~m}$ & $3057, \mathrm{~b}$ & $1590, s$ & $325, \mathrm{w}$ & $448, w$ \\
\hline 13. & $1241, s$ & $1039, \mathrm{~m}$ & $3044, \mathrm{~b}$ & $1596, s$ & $320, w$ & $400, w$ \\
\hline 14. & $1248, \mathrm{~s}$ & $1037, \mathrm{~m}$ & $3041, \mathrm{~b}$ & $1598, s$ & $328, \mathrm{w}$ & $402, \mathrm{w}$ \\
\hline 15. & $1255, \mathrm{~s}$ & $1034, \mathrm{~m}$ & $3012, \mathrm{~b}$ & $1560, s$ & $328, \mathrm{w}$ & $399, \mathrm{w}$ \\
\hline 16. & $1260, \mathrm{~s}$ & $1040, \mathrm{~m}$ & $3045, \mathrm{~b}$ & $1601, s$ & $325, w$ & $401, \mathrm{w}$ \\
\hline 17. & $1254, \mathrm{~s}$ & $1044, \mathrm{~m}$ & $3052, \mathrm{~b}$ & $1593, \mathrm{~s}$ & $330, w$ & $450, \mathrm{w}$ \\
\hline 18. & $1248, \mathrm{~s}$ & $1042, \mathrm{~m}$ & $3024, \mathrm{~b}$ & $1594, \mathrm{~s}$ & $331, \mathrm{w}$ & $452, \mathrm{w}$ \\
\hline 19. & $1249, \mathrm{~s}$ & $1042, \mathrm{~m}$ & $3049, \mathrm{~b}$ & $1598, \mathrm{~s}$ & $326, w$ & $442, w$ \\
\hline 20. & $1238, \mathrm{~s}$ & $1038, \mathrm{~m}$ & $3059, \mathrm{~b}$ & 1597, s & $328, w$ & $447, \mathrm{w}$ \\
\hline 21. & $1244, \mathrm{~s}$ & $1040, \mathrm{~m}$ & $3044, \mathrm{~b}$ & $1599, \mathrm{~s}$ & $325, w$ & $445, w$ \\
\hline 22. & $1239, \mathrm{~s}$ & $1041, \mathrm{~m}$ & $3028, \mathrm{~b}$ & $1598, \mathrm{~s}$ & $320, \mathrm{w}$ & $446, \mathrm{w}$ \\
\hline 23. & $1240, \mathrm{~s}$ & $1038, \mathrm{~m}$ & $3044, \mathrm{~b}$ & $1595, \mathrm{~s}$ & $315, \mathrm{w}$ & $451, \mathrm{w}$ \\
\hline 24. & $1248, \mathrm{~s}$ & $1039, \mathrm{~m}$ & 3045 , b & $1598, \mathrm{~s}$ & $312, \mathrm{w}$ & $450, \mathrm{w}$ \\
\hline
\end{tabular}

s: sharp, b: broad, m: medium, and w: weak; ${ }^{* *} v$ La-N for complexes 9-12 and 17-24 and $v$ La-P for complexes 13-16.

${ }^{*}$ S. number of the complexes is according to Table 1.

in the region $1044-1034 \mathrm{~cm}^{-1}$ without a shoulder favors the bidentate linkage of the dithiocarbonate ligands with lanthanum atom. The presence of a new band ascribed to $v(\mathrm{La}-\mathrm{S})$ was present in the region $331-310 \mathrm{~cm}^{-1}$, which is indicative of formation of La-S bond in these complexes. The IR spectra of the adducts (9-24) have showed all the bands observed in the parent lanthanum-dithiocarbonates and bands characteristic of donor ligands $\left(\mathrm{NC}_{5} \mathrm{H}_{5}, \mathrm{P}\left(\mathrm{C}_{6} \mathrm{H}_{5}\right)_{3}\right.$, $\mathrm{N}_{2} \mathrm{C}_{12} \mathrm{H}_{8}$ and $\mathrm{N}_{2} \mathrm{C}_{10} \mathrm{H}_{8}$ ) in the regions 455-442 and 402$399 \mathrm{~cm}^{-1}$, which may be assigned to $v(\mathrm{La}-\mathrm{N})$ and $v(\mathrm{La}-\mathrm{P})$ bonding modes, respectively. The IR spectral values of the complexes are given in Table 3.

3.1.3. ${ }^{1} \mathrm{H}$ NMR Spectra. In ${ }^{1} \mathrm{H}$ NMR spectra, the signals for the $-\mathrm{CH}_{3}$ (tolyl ring) and $-\mathrm{CH}_{2}$ (benzyl ring) protons were observed at $2.22-2.33$ and $4.50-4.61 \mathrm{ppm}$ as singlet. The protons of the $\mathrm{C}_{6} \mathrm{H}_{4}$ (tolyl) and $\mathrm{C}_{6} \mathrm{H}_{5}$ (benzyl ring) gave signals in the range 6.22-7.23 and 7.10-7.64 ppm as multiplets. This chemical shift has no deviation either to lower or higher field side compared to the parent ligands. There were two resonances for the ring protons of para complexes whereas four resonances were observed for ortho- and metaderivatives. ${ }^{1} \mathrm{H}$ NMR spectra of the addition complexes exhibited the characteristic proton signals of the tris $\left(o_{-}^{-}, m-\right.$, and $p$-tolyl/benzyldithicarbonate)lanthanum(III) complexes along with the chemical shifts for aromatic protons for the donor ligands. The chemical shifts for aromatic protons of triphenylphosphine moiety in the complexes $\mathbf{1 3 - 1 6}$ were observed in the region $7.22-7.61 \mathrm{ppm}$ as multiplet. In case of adducts with nitrogen donor ligand, the chemical shift for aromatic protons of pyridine in the complexes 9-12 was observedin the region $7.60-8.41 \mathrm{ppm}$ as multiplet. The complexes 17-20 have shown the characteristic resonances for phenyl protons of 1,10-phenanthroline at 7.23-8.91 ppm. The chemical shift for aryl protons of the bipyridine appeared in the region 7.10-8.59 ppm for complexes 21-24. The presence of all characteristic chemical shifts in the ${ }^{1} \mathrm{H}$ NMR spectra favors the formation of these complexes. The ${ }^{1} \mathrm{H}$ NMR spectral data of these complexes are given in Table 4 .

3.1.4. ${ }^{31} P$ NMR Spectra. ${ }^{31} \mathrm{P}$ NMR spectra of the addition complexes (13-16) exhibited the signal for the phosphorus atom of the triphenylphosphine moiety as a singlet at -4.52 to $-5.32 \mathrm{ppm}$. The ${ }^{31} \mathrm{P}$ NMR resonances of bound ligand are shifted to downfield compared with those of the free triphenylphosphine. The relevant ${ }^{31} \mathrm{P}$ NMR spectral data of these complexes are given in the Table 4 .

3.1.5. ${ }^{13} \mathrm{C}$ NMR Spectra. ${ }^{13} \mathrm{C}$ NMR spectra of few representative complexes $(6-7,11-12,14-15,17-18,21$, and 24) have shown the appearance of the chemical shift for all the carbon nuclei in their characteristic region. The chemical shift for methyl $\left(-\mathrm{CH}_{3}\right)$ and methylene $\left(-\mathrm{CH}_{2}\right)$ carbon occurred in the range 19.63-21.10 and 71.02-71.23 ppm, respectively. The carbon nuclei of phenyl groups $\left(-\mathrm{C}_{6} \mathrm{H}_{5}\right.$ and $\left.-\mathrm{C}_{6} \mathrm{H}_{4}\right)$ have displayed their resonance in the region 112.21-130.02 ppm. The carbon attached to the methyl and methylene substituted carbon of the phenyl ring in the respective compounds 
TABLE 4: ${ }^{1} \mathrm{H}$ and ${ }^{31} \mathrm{P}$ NMR spectral data of tolyl/benzyl dithiocarbonates of $\mathrm{La}(\mathrm{III})$ and their adducts in $\mathrm{CDCl}_{3}$ (in $\mathrm{ppm}$ ).

\begin{tabular}{|c|c|c|c|c|}
\hline $\begin{array}{l}\text { S. } \\
\text { number* }\end{array}$ & $-\mathrm{CH}_{3} / \mathrm{CH}_{2}$ & ${ }^{1} \mathrm{H}$ NMR Tolyl/benzyl moiety & Donor moiety & ${ }^{31} \mathrm{P}$ NMR \\
\hline 5. & $2.32, \mathrm{~s}, 9 \mathrm{H}\left(\mathrm{CH}_{3}\right)$ & $\begin{array}{l}\text { 6.81, d, } 3 \mathrm{H},\left[\mathrm{H}_{(2)}\right] ; 6.72, \mathrm{t}, 3 \mathrm{H},\left[\mathrm{H}_{(3)}\right] ; 6.90, \mathrm{t}, 3 \mathrm{H},\left[\mathrm{H}_{(4)}\right] ; 6.63 \\
\mathrm{~d}, 3 \mathrm{H},\left[\mathrm{H}_{(5)}\right]\end{array}$ & - & - \\
\hline 6. & $2.30, \mathrm{~s}, 9 \mathrm{H}\left(\mathrm{CH}_{3}\right)$ & $\begin{array}{l}\text { 6.50, s, } 3 \mathrm{H},\left[\mathrm{H}_{(1)}\right] ; 6.62, \mathrm{t}, 3 \mathrm{H},\left[\mathrm{H}_{(3)}\right] ; 6.91, \mathrm{t}, 3 \mathrm{H},\left[\mathrm{H}_{(4)}\right] ; 6.50 \\
\mathrm{~d}, 3 \mathrm{H},\left[\mathrm{H}_{(5)}\right]\end{array}$ & - & - \\
\hline 7. & $2.33, \mathrm{~s}, 9 \mathrm{H}\left(\mathrm{CH}_{3}\right)$ & $6.92, \mathrm{~d}, 6 \mathrm{H},\left[\mathrm{H}_{(1,5)}\right] ; 6.80, \mathrm{~d}, 6 \mathrm{H},\left[\mathrm{H}_{(2,4)}\right]$ & - & - \\
\hline 8. & $4.50, \mathrm{~s}, 6 \mathrm{H}\left(\mathrm{CH}_{2}\right)$ & $7.12-7.23, \mathrm{~m}, 15 \mathrm{H}\left(\mathrm{C}_{6} \mathrm{H}_{5}\right)$ & - & - \\
\hline 9. & $2.32, \mathrm{~s}, 9 \mathrm{H}\left(\mathrm{CH}_{3}\right)$ & $\begin{array}{l}\text { 6.74, d, } 3 \mathrm{H},\left[\mathrm{H}_{(2)}\right] ; 6.73, \mathrm{t}, 3 \mathrm{H},\left[\mathrm{H}_{(3)}\right] ; 6.91, \mathrm{t}, 3 \mathrm{H},\left[\mathrm{H}_{(4)}\right] ; 6.53 \\
\mathrm{~d}, 3 \mathrm{H},\left[\mathrm{H}_{(5)}\right]\end{array}$ & 7.61-8.41, m, 10H, $\left(\mathrm{NC}_{5} \mathrm{H}_{5}\right)$ & \\
\hline 10. & $2.32, \mathrm{~s}, 9 \mathrm{H}\left(\mathrm{CH}_{3}\right)$ & $\begin{array}{l}\text { 6.32, s, } 3 \mathrm{H},\left[\mathrm{H}_{(1)}\right] ; 6.61, \mathrm{t}, 3 \mathrm{H},\left[\mathrm{H}_{(3)}\right] ; 6.90, \mathrm{t}, 3 \mathrm{H},\left[\mathrm{H}_{(4)}\right] ; 6.22 \\
\mathrm{~d}, 3 \mathrm{H},\left[\mathrm{H}_{(5)}\right]\end{array}$ & $7.62-8.40, \mathrm{~m}, 10 \mathrm{H},\left(\mathrm{NC}_{5} \mathrm{H}_{5}\right)$ & - \\
\hline 11. & $2.24, \mathrm{~s}, 9 \mathrm{H}\left(\mathrm{CH}_{3}\right)$ & $7.11, \mathrm{~d}, 6 \mathrm{H},\left[\mathrm{H}_{(1,5)}\right] ; 6.82, \mathrm{~d}, 6 \mathrm{H},\left[\mathrm{H}_{(2,4)}\right]$ & $7.60-8.39, \mathrm{~m}, 10 \mathrm{H},\left(\mathrm{NC}_{5} \mathrm{H}_{5}\right)$ & - \\
\hline 12. & $4.51, \mathrm{~s}, 6 \mathrm{H}\left(\mathrm{CH}_{2}\right)$ & $7.12-7.42, \mathrm{~m}, 15 \mathrm{H}\left(\mathrm{C}_{6} \mathrm{H}_{5}\right)$ & $7.64-8.02, \mathrm{~m}, 10 \mathrm{H},\left(\mathrm{NC}_{5} \mathrm{H}_{5}\right)$ & - \\
\hline 13. & $2.23, \mathrm{~s}, 9 \mathrm{H}\left(\mathrm{CH}_{3}\right)$ & $\begin{array}{l}\text { 6.80, d, } 3 \mathrm{H},\left[\mathrm{H}_{(2)}\right] ; 6.70, \mathrm{t}, 3 \mathrm{H},\left[\mathrm{H}_{(3)}\right] ; 6.92, \mathrm{t}, 3 \mathrm{H},\left[\mathrm{H}_{(4)}\right] ; 6.61, \\
\mathrm{~d}, 3 \mathrm{H},\left[\mathrm{H}_{(5)}\right]\end{array}$ & $7.24-7.61, \mathrm{~m}, 30 \mathrm{H},\left(\mathrm{PPh}_{3}\right)$ & $-5.01, \mathrm{~s}$ \\
\hline 14. & $2.32, \mathrm{~s}, 9 \mathrm{H}\left(\mathrm{CH}_{3}\right)$ & $\begin{array}{l}\text { 6.42, s, } 3 \mathrm{H},\left[\mathrm{H}_{(1)}\right] ; 6.70, \mathrm{t}, 3 \mathrm{H},\left[\mathrm{H}_{(3)}\right] ; 7.13, \mathrm{t}, 3 \mathrm{H},\left[\mathrm{H}_{(4)}\right] ; 6.44 \\
\mathrm{~d}, 3 \mathrm{H},\left[\mathrm{H}_{(5)}\right]\end{array}$ & $7.23-7.59, \mathrm{~m}, 30 \mathrm{H},\left(\mathrm{PPh}_{3}\right)$ & $-5.32, \mathrm{~s}$ \\
\hline 15. & $2.33, \mathrm{~s}, 9 \mathrm{H}\left(\mathrm{CH}_{3}\right)$ & $6.92, \mathrm{~d}, 6 \mathrm{H},\left[\mathrm{H}_{(1,5)}\right] ; 6.83, \mathrm{~d}, 6 \mathrm{H},\left[\mathrm{H}_{(2,4)}\right]$ & 7.22-7.61, m, 30H, $\left(\mathrm{PPh}_{3}\right)$ & $-4.52, \mathrm{~s}$ \\
\hline 16. & $4.61, \mathrm{~s}, 6 \mathrm{H}\left(\mathrm{CH}_{2}\right)$ & $7.12-7.51, \mathrm{~m}, 15 \mathrm{H}\left(\mathrm{C}_{6} \mathrm{H}_{5}\right)$ & $7.23-7.60, \mathrm{~m}, 30 \mathrm{H},\left(\mathrm{PPh}_{3}\right)$ & $-4.90, \mathrm{~s}$ \\
\hline 17. & $2.30, \mathrm{~s}, 9 \mathrm{H}\left(\mathrm{CH}_{3}\right)$ & $\begin{array}{l}\text { 6.80, d, } 3 \mathrm{H},\left[\mathrm{H}_{(2)}\right] ; 6.74, \mathrm{t}, 3 \mathrm{H},\left[\mathrm{H}_{(3)}\right] ; 6.95, \mathrm{t}, 3 \mathrm{H},\left[\mathrm{H}_{(4)}\right] ; 6.62 \\
\mathrm{~d}, 3 \mathrm{H},\left[\mathrm{H}_{(5)}\right]\end{array}$ & $7.31-8.90, \mathrm{~m}, 8 \mathrm{H},\left(\mathrm{N}_{2} \mathrm{C}_{12} \mathrm{H}_{8}\right)$ & - \\
\hline 18. & $2.31, \mathrm{~s}, 9 \mathrm{H}\left(\mathrm{CH}_{3}\right)$ & $\begin{array}{l}\text { 6.52, s, } 3 \mathrm{H},\left[\mathrm{H}_{(1)}\right] ; 6.63, \mathrm{t}, 3 \mathrm{H},\left[\mathrm{H}_{(3)}\right] ; 6.94, \mathrm{t}, 3 \mathrm{H},\left[\mathrm{H}_{(4)}\right] ; 6.52 \\
\mathrm{~d}, 3 \mathrm{H},\left[\mathrm{H}_{(5)}\right]\end{array}$ & 7.32-8.91, m, 8H, $\left(\mathrm{N}_{2} \mathrm{C}_{12} \mathrm{H}_{8}\right)$ & - \\
\hline 19. & $2.32, \mathrm{~s}, 9 \mathrm{H}\left(\mathrm{CH}_{3}\right)$ & $6.90, \mathrm{~d}, 6 \mathrm{H},\left[\mathrm{H}_{(1,5)}\right] ; 6.72, \mathrm{~d}, 6 \mathrm{H},\left[\mathrm{H}_{(2,4)}\right]$ & $7.32-8.89, \mathrm{~m}, 8 \mathrm{H},\left(\mathrm{N}_{2} \mathrm{C}_{12} \mathrm{H}_{8}\right)$ & - \\
\hline 20. & $4.50, \mathrm{~s}, 6 \mathrm{H}\left(\mathrm{CH}_{2}\right)$ & $7.10-7.22, \mathrm{~m}, 15 \mathrm{H}\left(\mathrm{C}_{6} \mathrm{H}_{5}\right)$ & $7.23-8.91, \mathrm{~m}, 8 \mathrm{H},\left(\mathrm{N}_{2} \mathrm{C}_{12} \mathrm{H}_{8}\right)$ & - \\
\hline 21. & $2.31, \mathrm{~s}, 9 \mathrm{H}\left(\mathrm{CH}_{3}\right)$ & $\begin{array}{l}\text { 6.81, d, } 3 \mathrm{H},\left[\mathrm{H}_{(2)}\right] ; 6.72, \mathrm{t}, 3 \mathrm{H},\left[\mathrm{H}_{(3)}\right] ; 6.92, \mathrm{t}, 3 \mathrm{H},\left[\mathrm{H}_{(4)}\right] ; 6.62 \\
\mathrm{~d}, 3 \mathrm{H},\left[\mathrm{H}_{(5)}\right]\end{array}$ & $7.12-8.52, \mathrm{~m}, 8 \mathrm{H},\left(\mathrm{N}_{2} \mathrm{C}_{10} \mathrm{H}_{8}\right)$ & - \\
\hline 22. & $2.22, \mathrm{~s}, 9 \mathrm{H}\left(\mathrm{CH}_{3}\right)$ & $\begin{array}{l}6.42, \mathrm{~s}, 3 \mathrm{H},\left[\mathrm{H}_{(1)}\right] ; 6.71, \mathrm{t}, 3 \mathrm{H},\left[\mathrm{H}_{(3)}\right] ; 7.23, \mathrm{t}, 3 \mathrm{H},\left[\mathrm{H}_{(4)}\right] ; 6.52, \mathrm{~d} \text {, } \\
3 \mathrm{H},\left[\mathrm{H}_{(5)}\right]\end{array}$ & $7.10-8.55, \mathrm{~m}, 8 \mathrm{H},\left(\mathrm{N}_{2} \mathrm{C}_{10} \mathrm{H}_{8}\right)$ & \\
\hline 23. & $2.32, \mathrm{~s}, 9 \mathrm{H}\left(\mathrm{CH}_{3}\right)$ & $6.92, \mathrm{~d}, 6 \mathrm{H},\left[\mathrm{H}_{(1,5)}\right] ; 6.80, \mathrm{~d}, 6 \mathrm{H},\left[\mathrm{H}_{(2,4)}\right]$ & $7.13-8.58, \mathrm{~m}, 8 \mathrm{H},\left(\mathrm{N}_{2} \mathrm{C}_{10} \mathrm{H}_{8}\right)$ & - \\
\hline 24. & $4.60, \mathrm{~s}, 6 \mathrm{H}\left(\mathrm{CH}_{2}\right)$ & $7.12-7.64, \mathrm{~m}, 15 \mathrm{H}\left(\mathrm{C}_{6} \mathrm{H}_{5}\right)$ & $7.12-8.59, \mathrm{~m}, 8 \mathrm{H},\left(\mathrm{N}_{2} \mathrm{C}_{10} \mathrm{H}_{8}\right)$ & - \\
\hline
\end{tabular}

s: singlet, d: doublet, t: triplet, and m: multiplet; ${ }^{*}$ S. number of the complexes is according to Table 1.

appeared at 123.51-139.50 and 137.41-138.03 ppm, respectively. The peak in the region $152.10-158.90 \mathrm{ppm}$ was due to the carbon attached to the oxygen in the tolyl derivatives. The chemical shift for the dithiocarbonate carbon $\left(-(\mathrm{O}) \mathrm{CS}_{2}\right)$ appeared at $164.00-169.16 \mathrm{ppm}$. The ${ }^{13} \mathrm{C}$ NMR spectra of the addition complexes exhibited the signals of the carbon nucleus of the donor moieties in addition to the characteristic chemical shifts indicated above. The aryl carbon nuclei of the pyridine (11-12) and triphenylphosphine (14-15) resonated at 118.71-148.02 ppm and 127.02-138.01 ppm, respectively. The aryl carbon nuclei of the phenanthroline (17-18) and bipyridine (21-24) gave their resonance at $120.02-150.00 \mathrm{ppm}$ and 120.12-153.80 ppm, respectively. The ${ }^{13} \mathrm{C}$ NMR spectral data of the complexes are given in the Table 5.

3.1.6. Thermogravimetric Analysis. The thermal properties of the complexes were studied by TGA in the temperature ranging from $30-1000^{\circ} \mathrm{C}$ under nitrogen atmosphere. The content of a particular component in a complex changes with its composition and structure. These can be determined based on mass losses of these components in the thermogravimetric plots of the complexes. The thermogravimetric analysis of the complex, $\left[\mathrm{La}\left(p-\mathrm{CH}_{3} \mathrm{C}_{6} \mathrm{H}_{4} \mathrm{OCS}_{2}\right)_{3}\right]$ (5) displayed a thermolysis step that covers a temperature range from 150 to $900^{\circ} \mathrm{C}$. The thermogram (Figure 1) exhibited the decline curve characteristic for dithiocarbonate complexes. The diagnostic weight loss of initial weight occurs in the steeply descending segment of the TGA curve. This weight loss, that is, $27.5 \%$ at $243.4^{\circ} \mathrm{C}$, is due to the decomposition of the dithiocarbonate corresponding to $\left[\mathrm{La}\left(p-\mathrm{CH}_{3} \mathrm{C}_{6} \mathrm{H}_{4} \mathrm{OCS}_{2}\right)_{2}\right]$, (the calculated weight loss is $26.7 \%$ ) as an intermediate product, which agrees with thermogravimetric data for dithiocarbonates. Another important weight loss $47.3 \%$ (obs.) occurs at $558.5^{\circ} \mathrm{C}$ temperature corresponding to the formation of $\left[\mathrm{La}\left(\mathrm{OCS}_{2}\right)_{2}\right]$ 
TABLE 5: ${ }^{13} \mathrm{C}$ NMR spectral data of tolyl/benzyl dithiocarbonates of $\mathrm{La}(\mathrm{III})$ and their adducts in $\mathrm{CDCl}_{3}$ (in ppm).

\begin{tabular}{|c|c|c|c|c|c|c|c|c|c|c|}
\hline \multirow{3}{*}{$\begin{array}{l}\text { S. } \\
\text { number* }\end{array}$} & \multirow{3}{*}{$-\mathrm{CH}_{3} / \mathrm{CH}_{2}$} & \multirow{2}{*}{\multicolumn{8}{|c|}{ Tolyl/benzyl moiety }} & \multirow{3}{*}{ Donor moiety } \\
\hline & & & & & & & & & & \\
\hline & & $-\mathrm{C}_{(1)}$ & $-\mathrm{C}_{(2)}$ & $-\mathrm{C}_{(3)}$ & $-\mathrm{C}_{(4)}$ & $-\mathrm{C}_{(5)}$ & $-\mathrm{C}_{(6)}$ & $-\mathrm{C}\left(\mathrm{CH}_{3}\right)$ & $-\mathrm{O}\left(\mathrm{CS}_{2}\right)$ & \\
\hline 6. & 20.12 & 155.81 & 115.02 & - & 120.02 & 128.91 & 112.22 & 139.50 & 168.40 & - \\
\hline 7. & 19.63 & 152.11 & 114.49 & 129.25 & - & 129.25 & 114.49 & 129.33 & 164.44 & - \\
\hline 11. & 19.71 & 152.1 & 114.16 & 128.18 & - & 128.18 & 114.16 & 129.24 & 169.16 & $118.71-147.26$ \\
\hline 12. & 71.23 & 138.03 & 126.01 & 127.43 & 127.90 & 127.50 & 126.13 & - & 168.02 & $119.94-148.02$ \\
\hline 14. & 20.12 & 155.91 & 115.02 & - & 119.32 & 128.9 & 112.21 & 138.50 & 166.84 & $127.02-138.01$ \\
\hline 15. & 20.53 & 153.72 & 115.26 & 128.54 & - & 128.54 & 115.26 & 130.00 & 164.00 & $128.61-136.86$ \\
\hline 17. & 21.10 & 158.90 & - & 130.02 & 121.82 & 127.80 & 114.90 & 123.51 & 168.91 & $120.02-150.00$ \\
\hline 18. & 20.22 & 157.32 & 115.02 & - & 122.43 & 128.01 & 112.32 & 138.16 & 167.88 & $122.01-149.05$ \\
\hline 21. & 20.24 & 155.02 & - & 129.88 & 117.64 & 127.01 & 117.64 & 124.70 & 164.00 & $120.61-150.81$ \\
\hline 24. & 71.02 & 137.4 & 126.11 & 127.51 & 128.01 & 127.60 & 126.21 & - & 166.91 & $120.12-153.80$ \\
\hline
\end{tabular}

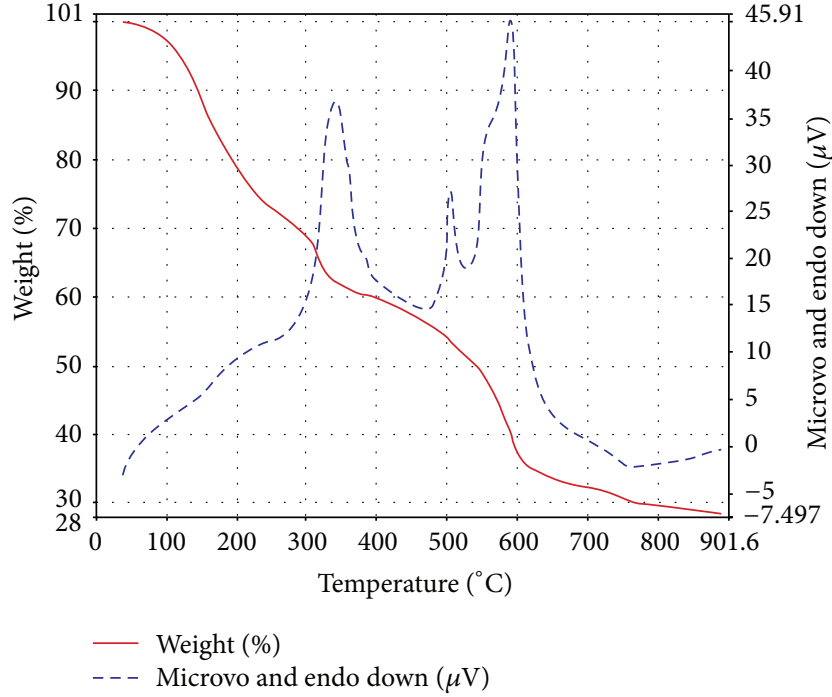

FIgURE 1: TGA curve of the complex $\left[\mathrm{La}\left(p-\mathrm{CH}_{3} \mathrm{C}_{6} \mathrm{H}_{4} \mathrm{OCS}_{2}\right)_{3}\right](5)$.

(weight loss calculated 47.0\%). The decomposition continues to about $800^{\circ} \mathrm{C}$ at which most of the organic part of the compound has been lost. This sharp decomposition period brings about $68-71 \%$ weight loss in the lanthanum complex and led to the complete formation of metal sulfide, that is, $\mathrm{LaS}_{2}$ (weight loss calculated $70.5 \%$, observed 70.6\%), at $813^{\circ} \mathrm{C}$. The calculated mass change agrees favorably with experimental values.

\subsubsection{Antimicrobial Activity}

(1) Antibacterial to Antifungal. The in vitro biological screening effects of all the ligands and some of the complexes (5, 10, 15, 20, and 23) were tested against the fungus Fusarium oxysporum f. sp. Capsici causing vascular wilt of chilli. The

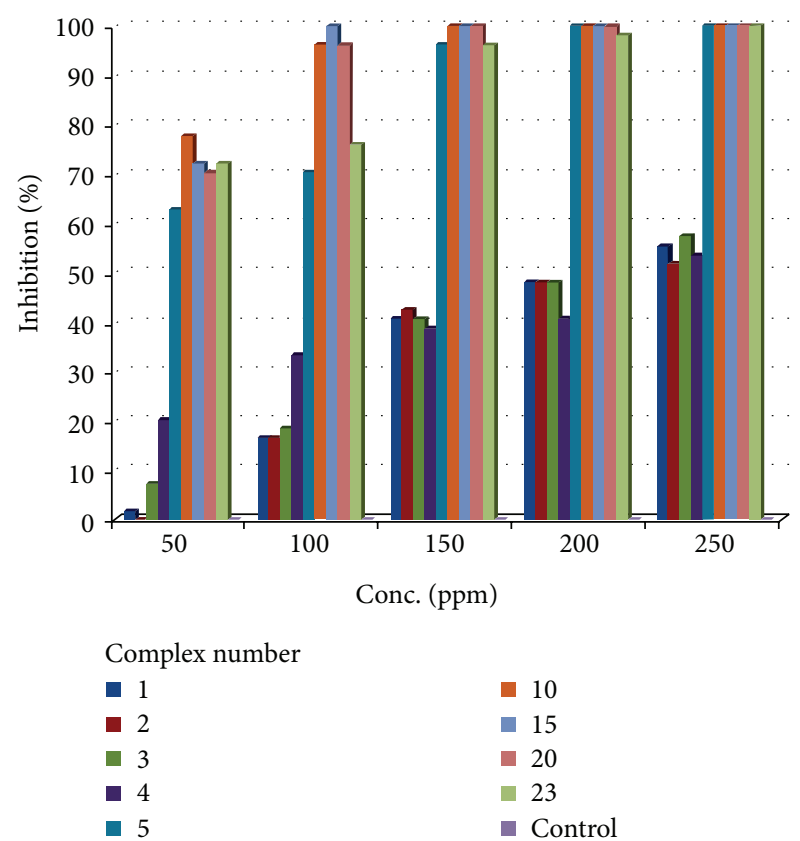

FIGURE 2: Comparison of antifungal activity of the ligands and their lanthanum(III) complexes.

antifungal screening data are given in Table 6, which shows that complexes have higher activity than free ligands. The colony diameter of the fungus decreases on enhancing the concentration of the complex; that is, all the complexes inhibited the growth of fungus significantly. This shows a linear relationship between concentration and percent inhibition. The increase in antifungal activity may be attributed to faster diffusion of metal complexes as a whole through the cell membrane or due to combined activity effect of the metal and the ligand. It is also evident from the antifungal 


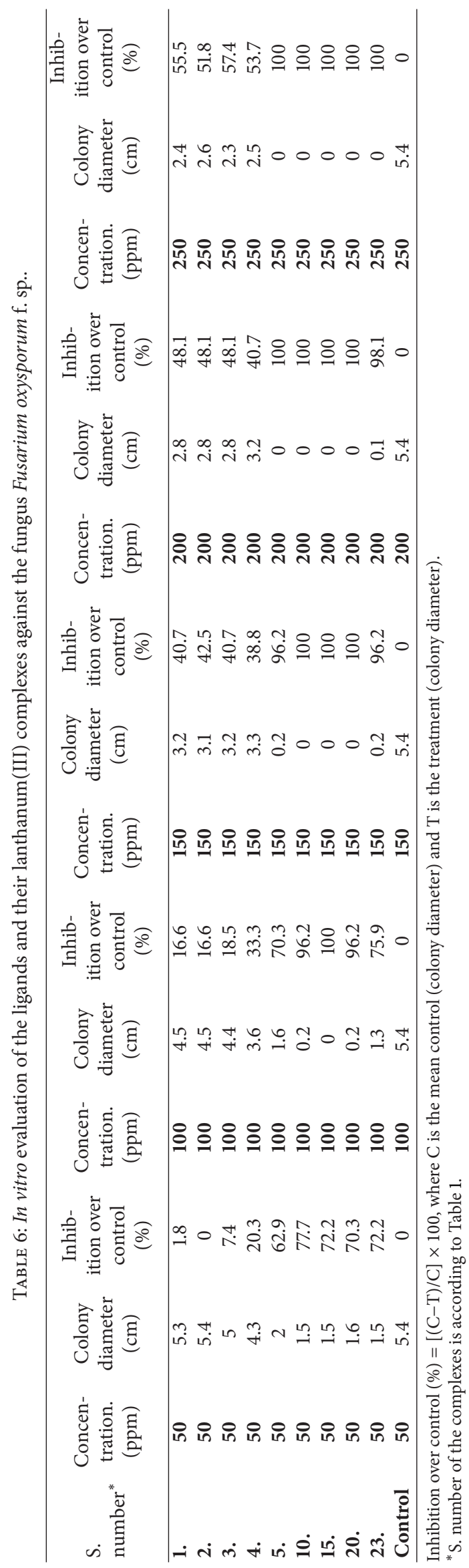




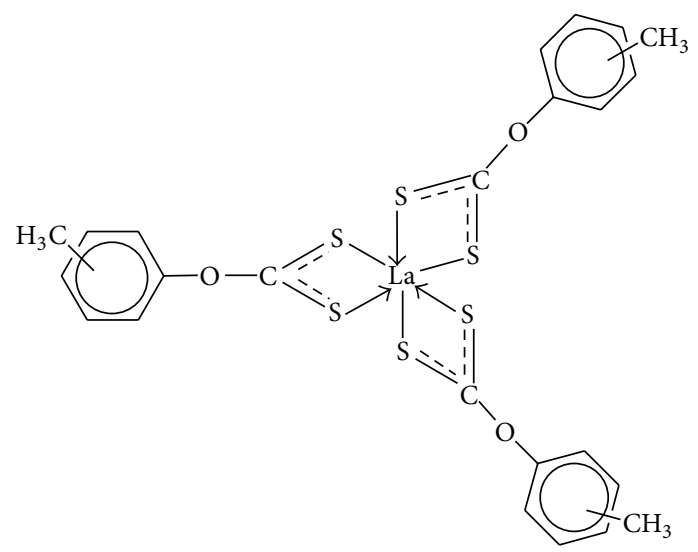

(a)

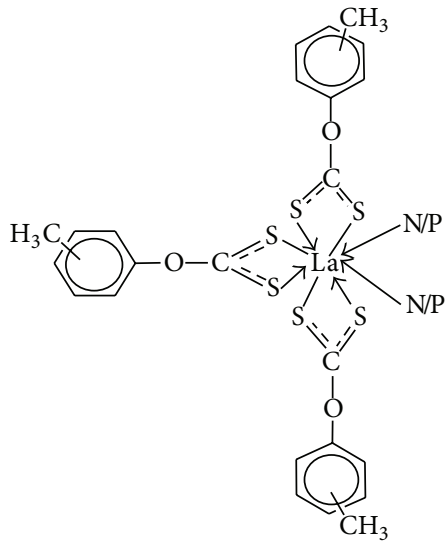

(b)

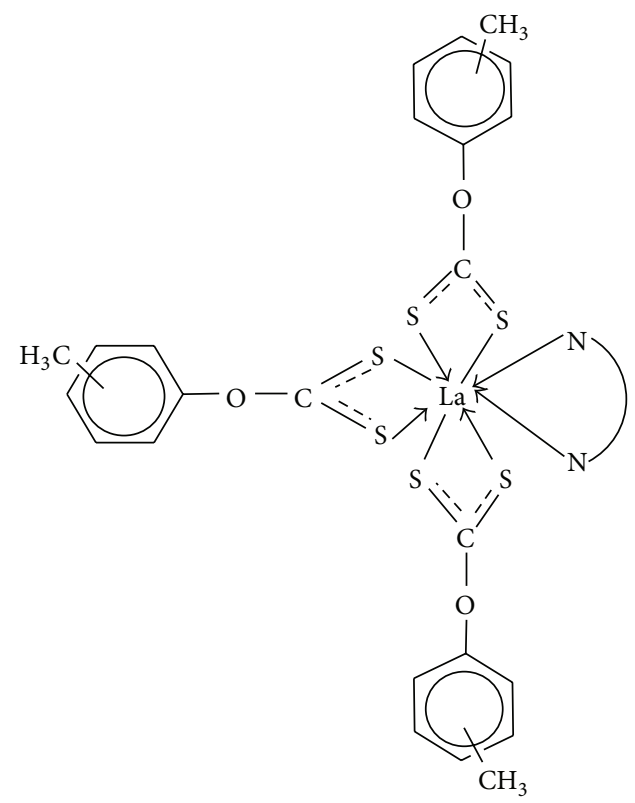

(c)

Figure 3: (a) Proposed hexacoordinate structure for $\left[\mathrm{La}\left(o-, m \text { - and } p-\mathrm{CH}_{3} \mathrm{C}_{6} \mathrm{H}_{4} \mathrm{OCS}_{2}\right)_{3}\right]$ (5-7). (b) Proposed octacoordinate structure for $\left[\mathrm{La}\left(o-, m \text { - and } p-\mathrm{CH}_{3} \mathrm{C}_{6} \mathrm{H}_{4} \mathrm{OCS}_{2}\right)_{3} .2 \mathrm{~N} / \mathrm{P}\right](9-11,13-15)\left[\mathrm{N}=\mathrm{NC}_{5} \mathrm{H}_{5}\left(\right.\right.$ 9-12) and $\mathrm{P}=\mathrm{P}\left(\mathrm{C}_{6} \mathrm{H}_{5}\right)_{3}$ (13-15)]. (c) Proposed octacoordinate structure for $\left[\mathrm{La}\left(o-, m \text { - and } p-\mathrm{CH}_{3} \mathrm{C}_{6} \mathrm{H}_{4} \mathrm{OCS}_{2}\right)_{3} \cdot \mathrm{N}_{2} \mathrm{C}_{12} \mathrm{H}_{8} / \mathrm{N}_{2} \mathrm{C}_{10} \mathrm{H}_{8}\right][(17-19,21-23)]$.

screening data that adducts of nitrogen and phosphorous donor ligands are more potent than the parent complex. The chelation theory accounts for the increased activity of the metal complexes [41]. On chelating, the polarity of the metal ion will be reduced to a greater extent due to overlap of the ligand orbital and the partial sharing of the positive charge of the metal ion with donor group. The comparison of antifungal activity of all the ligands and some of the complexes is described diagrammatically in Figure 2.

(2) Antibacterial Activity. Antibacterial in vitro studies against two bacterial strains involve Gram-negative Klebsiella pneumonia and Gram-positive Bacillus cereus using penicillin as standard antibacterial drug. Antibacterial screening data are given in Table 7. These studies revealed that free ligands are inactive against the bacterial strains but metal complexes shows higher activity than free ligands but lower activity than reference drug that is, penicillin. However, the complex $\left[\mathrm{La}\left(\mathrm{C}_{6} \mathrm{H}_{4} \mathrm{CH}_{2} \mathrm{OCS}_{2}\right)_{3} \cdot \mathrm{N}_{2} \mathrm{C}_{12} \mathrm{H}_{8}\right]$ (20) shows pronounced activity against Klebsiella pneumonia and Bacillus cereus even more than reference drug.

\section{Conclusions}

On the basis of elemental analysis, mass, IR, and NMR $\left({ }^{1} \mathrm{H},{ }^{13} \mathrm{C}\right.$ and ${ }^{31} \mathrm{P}$ NMR $)$ spectral studies and in conjunction with the literature reports [39, 42-45], a hexacoordinate structure may be proposed for lanthanum(III)tris $(O$ tolyl/benzyldithiocarbonates) (5-8) in Figure 3(a) and octacoordinate structure may be proposed for adducts of lanthanum(III)tris (O-tolyl/benyldithiocarbonates) (9-24) in which tolyldithiocarbonate ligands behaved in bidentate 
TABLE 7: Antibacterial screening of the ligands and their lanthanum(III) complexes.

\begin{tabular}{|c|c|c|c|c|c|c|}
\hline \multirow{3}{*}{ S. number* } & \multicolumn{6}{|c|}{ Diameter of inhibition zone $(\mathrm{cm})$ (conc. in ppm) } \\
\hline & \multicolumn{3}{|c|}{ Klebsiella pneumonia $(-)$} & \multicolumn{3}{|c|}{ Bacillus cereus $(+)$} \\
\hline & $250 \mathrm{ppm}$ & $500 \mathrm{ppm}$ & $1000 \mathrm{ppm}$ & $250 \mathrm{ppm}$ & $500 \mathrm{ppm}$ & $1000 \mathrm{ppm}$ \\
\hline 1. & N.I & N.I & N.I & N.I & N.I & N.I \\
\hline 2. & N.I & N.I & N.I & N.I & N.I & N.I \\
\hline 3. & N.I & N.I & N.I & N.I & N.I & N.I \\
\hline 4. & N.I & N.I & N.I & N.I & N.I & N.I \\
\hline 5. & 1.3 & 1.9 & 2.2 & 0.9 & 1.3 & 1.4 \\
\hline 10. & 1.6 & 2.5 & 2.7 & 2.2 & 2.7 & 3.2 \\
\hline 15. & 2.2 & 2.8 & 3.2 & 0.8 & 1.7 & 2.2 \\
\hline 20. & 2.4 & 3.5 & 3.6 & 2.8 & 3.4 & 3.6 \\
\hline 23. & 0.6 & 2.1 & 2.3 & 1.6 & 2.6 & 2.9 \\
\hline Penicillin. & 2.2 & 2.6 & 2.9 & 2.4 & 2.8 & 2.9 \\
\hline
\end{tabular}

N.I: no inhibition; ${ }^{*}$ S. number of the complexes is according to Table 1.

manner. Hence, the lanthanum atom is coordinated by six sulfur atoms of the dithiocarbonate and two nitrogen atoms of the two pyridine molecules in the compounds 9-12 as shown in Figure 3(b). In the compounds 13-16 lanthanum atom is coordinated with the two phosphorus atoms of the two triphenylphosphine molecules and six sulfur atoms of the dithiocarbonate Figure 3(b). The octacoordination by lanthanum in the compounds $\mathbf{1 7 - 2 4}$ is achieved by coordination with six sulfur atoms of dithiocarbonate ligand and two nitrogen atoms of phenanthroline and bipyridyl molecule as described in Figure 3(c). The benzyl analogues $(\mathbf{8}, \mathbf{1 2}, \mathbf{1 6}, \mathbf{2 0}$, and 24) have similar structures.

\section{Conflict of Interests}

The authors declare that there is no conflict of interests regarding the publication of this paper.

\section{Acknowledgments}

Sushil K. Pandey gratefully acknowledges the financial assistance from the University Grants Commission, New Delhi. The authors are grateful to SAIF (Sophisticated Analytical Instrumentation Facility), University of Panjab, Chandigarh, and the Indian Institute of Integrative Medicine, Jammu, for providing spectral facilities.

\section{References}

[1] R. F. Semeniuc, T. J. Reamer, J. P. Blitz, K. A. Wheeler, and M. D. Smith, "Functionalized $O$-alkyldithiocarbonates: a new class of ligands designed for luminescent heterometallic materials," Inorganic Chemistry, vol. 49, no. 6, pp. 2624-2629, 2010.

[2] B. Gupta, N. Kalgotra, S. Andotra, and S. K. Pandey, "OTolyl/benzyl dithiocarbonates of phosphorus(III) and (V): syntheses and characterization," Monatshefte für Chemie, vol. 143, no. 7, pp. 1087-1095, 2012.

[3] O. V. Bakbardina, I. Y. Pukhnyarskaya, M. A. Gazalieva, S. D. Fazylov, and E. M. Makarov, "Synthesis and fungicidal activity of $S$-amino derivatives of $O$-alkyldithiocarbonic acids," Russian Journal of Applied Chemistry, vol. 79, no. 10, pp. 1726-1728, 2006.

[4] A. A. Abramov and K. S. E. Forssberg, "Chemistry and optimal conditions for copper minerals flotation: theory and practice," Mineral Processing and Extractive Metallurgy Review, vol. 26, no. 2, pp. 77-143, 2005.

[5] S. Chaudhari and V. Tare, "Heavy metal-soluble starch xanthate interactions in aqueous environments," Journal of Applied Polymer Science, vol. 71, no. 8, pp. 1325-1332, 1999.

[6] G. Winter, "Inorganic xanthates," Reviews in Inorganic Chemistry, vol. 2, pp. 253-342, 1980.

[7] E. R. T. Tiekink and G. Winter, "Inorganic xanthates: a structural perspective," Reviews in Inorganic Chemistry, vol. 12, no. 3-4, pp. 183-302, 1992.

[8] B. F. Hoskins and C. D. Pannan, "A novel five-co-ordinate pentagonal-planar complex: $X$-ray structure of the tris-(O-ethyl xanthato)tellurate(II) anion," Journal of the Chemical Society, Chemical Communications, no. 11, pp. 408-409, 1975.

[9] D. Dakternieks, R. di Giacomo, R. W. Gable, and B. F. Hoskins, "Synthesis, NMR study and crystal structures of bis(diethyldithiocarbamato)-(O, $O^{\prime}$ diethyldithiophosphato)phenyl tellurium (IV), $\mathrm{PhTe}\left(\mathrm{S}_{2} \mathrm{CNEt}_{2}\right)_{2}\left[\mathrm{~S}_{2} \mathrm{P}(\mathrm{OEt})_{2}\right]$, and bis(diethyldithiocarbamato)Iodomethyl tellurium(IV), $\mathrm{MeTe}(\mathrm{I})\left(\mathrm{S}_{2} \mathrm{CNEt}_{2}\right)_{2}$," Journal of the American Chemical Society, vol. 110, no. 20, pp. 67626768, 1988.

[10] E. R. T. Tiekink and I. Haiduc, "Stereochemical aspects of metal xanthate complexes: molecular structures and supramolecular self-assembly," in Progress in Inorganic Chemistry, vol. 54, pp. 127-319, John Wiley \& Sons, New York, NY, USA, 2005.

[11] K. Xu and W. Ding, "Controlled synthesis of spherical CuS hierarchical structures," Materials Letters, vol. 62, no. 29, pp. 4437-4439, 2008.

[12] Q. Han, J. Chen, X. Yang, L. Lu, and X. Wang, "Preparation of uniform $\mathrm{Bi}_{2} \mathrm{~S}_{3}$ nanorods using xanthate complexes of bismuth (III)," The Journal of Physical Chemistry C, vol. 111, no. 38, pp. 14072-14077, 2007.

[13] D. E. Zelmon, Z. Gebeyehu, D. Tomlin, and Th. M. Copper, "Investigation of transition metal-xanthate complexes for nonlinear optical applications," Material Research Society Symposia Proceeding, vol. 519, pp. 395-401, 1998. 
[14] N. Kalgotra, B. Gupta, K. Kumar, and S. K. Pandey, "Otolyldithiocarbonate complexes of iron(II) and iron(III)," Phosphorus, Sulfur and Silicon and the Related Elements, vol. 187, no. 3, pp. 364-375, 2012.

[15] W. M. Doane, B. S. Shasha, and C. R. Russel, "Encapsulation of pesticides within starch matrix," in Controlled Release Pesticides, vol. 53 of ACS Symposium Series, pp. 74-83, American Chemical Society, Washington, DC, USA, 1977.

[16] M. Scendo, "Potassium ethyl xanthate as corrosion inhibitor for copper in acidic chloride solutions," Corrosion Science, vol. 47, no. 7, pp. 1738-1749, 2005.

[17] W. J. Orts, R. E. Sojka, and G. M. Glenn, "Polymer additives in irrigation water to reduce erosion and better manage water infiltration," Agro Food Industry, vol. 13, no. 4, pp. 37-41, 2002.

[18] O. A. Gorgulu, M. Arslan, and E. Cil, "Synthesis and characterization of potassium 1,3-Bis(N-methylpiperazino) propan-2-Oxanthate and the complexes of $\mathrm{Co}(\mathrm{II}), \mathrm{Ni}(\mathrm{II})$ and $\mathrm{Cu}(\mathrm{I})$ ions," Journal of Coordination Chemistry, vol. 59, no. 6, pp. 637-642, 2006.

[19] A.-C. Larsson and S. Oberg, "Study on potassium iso propylxanthate and its decomposition products: experimental ${ }^{13} \mathrm{C}$ CP/MAS NMR combined with DFT calculations," The Journal of Physical Chemistry A, vol. 115, no. 8, pp. 1396-1407, 2011.

[20] E. Amtmann, "The antiviral, antitumoural xanthate D609 is a competitive inhibitor of phosphatidylcholine-specific phospholipase C," Drugs under Experimental and Clinical Research, vol. 22, no. 6, pp. 287-294, 1996.

[21] M. Perluigi, G. Joshi, R. Sultana et al., "In vivo protection by the xanthate tricyclodecan-9-yl-xanthogenate against amyloid $\beta$-peptide (1 -42)-induced oxidative stress," Neuroscience, vol. 138, no. 4, pp. 1161-1170, 2006.

[22] A. K. Chaturvedi, D. Chaturvedi, N. Mishra, and V. Mishra, "A high yielding, one-pot synthesis of S,S-dialkyl dithiocarbonates through the corresponding thiols using Mitsunobu's reagent," Journal of the Iranian Chemical Society, vol. 7, no. 3, pp. 702706, 2010.

[23] M. Tliha, H. Mathlouthi, J. Lamloumi, and A. J. PercheronGuegan, " $\mathrm{AB}_{5}$-type hydrogen storage alloy used as anodic materials in Ni-MH batteries," Journal of Alloys and Compounds, vol. 436, no. 1-2, pp. 221-225, 2007.

[24] S. Shahzadi, S. Ali, R. Jabeen, and M. K. Khosa, "[Pd(Mexanthate) ${ }_{2}$ : synthesis, characterization, and X-ray structure," Turkish Journal of Chemistry, vol. 33, no. 2, pp. 307-312, 2009.

[25] H. B. Kagan, "Introduction: frontiers in lanthanide chemistry," Chemical Reviews ACS, vol. 102, no. 6, pp. 1805-1806, 2002.

[26] S. Prasad, R. K. Agarwal, and A. Kumar, "Synthesis, characterization and biological evaluation of a novel series of mixed ligand complexes of lanthanides(III) with $4[\mathrm{~N}-$ (furfural)amino]antipyrine semicarbazone as primary ligand and diphenyl sulfoxide as secondary ligand," Journal of the Iranian Chemical Society, vol. 8, no. 3, pp. 825-839, 2011.

[27] Y. Jung and Y. M. Kim, "Evaluation of cellulose xanthate-metaltetracycline complexes as a polymeric antibacterial agent with prolonged antibacterial activity," Drug Delivery, vol. 15, no. 1, pp. 31-35, 2008.

[28] M. S. Joy and W. F. Finn, "Randomized, double-blind, placebocontrolled, dose-titration, phase III study assessing the efficacy and tolerability of lanthanum carbonate: a new phosphate binder for the treatment of hyperphosphatemia," American Journal of Kidney Diseases, vol. 42, no. 1, pp. 96-107, 2003.
[29] G. Exarchos, S. D. Robinson, and J. W. Steed, "The synthesis of new bimetallic complex salts by halide/sulfur chelate cross transfer: X-ray crystal structures of the salts $\left[\mathrm{Ni}\left(\mathrm{S}_{2} \mathrm{CNEt}\right)_{2}\right.$ (dppe $)_{2}\left[\mathrm{HgBr}_{4}\right], \quad\left[\mathrm{Pt}\left(\mathrm{S}_{2} \mathrm{CNEt}_{2}\right)_{2}(\mathrm{dppe})_{2}\right]_{2}\left[\mathrm{Cl}_{3} \mathrm{ZnO}:(\mathrm{Ph})_{2} \mathrm{PCH}_{2}\right.$ $\left.\mathrm{CH}_{2} \mathrm{P}(\mathrm{Ph})_{2}: \mathrm{OZnCl}_{3}\right]$ and $\left[\mathrm{Pd}\left(\mathrm{S}_{2} \mathrm{CN}^{n} \mathrm{Bu}_{2}\right)(\text { biby })\right]_{2}\left[\mathrm{CdCI}_{4}\right]$," Polyhedron, vol. 20, no. 24-25, pp. 2951-2963, 2001.

[30] M. J. Cox and E. R. T. Tiekink, "Crystal structure of tris( $O$-isopropyldithiocarbonato)cobalt(III), $\mathrm{C}_{12} \mathrm{H}_{21} \mathrm{CoO}_{3} \mathrm{~S}_{6}$," Zeitschrift fur Kristallograhie, vol. 211, no. 10, pp. 753-754, 1996.

[31] S. Vastag, L. Markó, and A. L. Rheingold, "Mononuclear cobalt carbonyls containing monodentate thiolate or xanthate groups. The structures of $\mathrm{PhSCo}(\mathrm{CO})_{2}\left(\mathrm{PPh}_{2} \mathrm{OMe}\right)_{2}$ and $\mathrm{MeOCS}_{2} \mathrm{Co}(\mathrm{CO})_{2}\left(\mathrm{PPh}_{2}^{i} \mathrm{Bu}\right)_{2}$," Journal of Organometallic Chemistry, vol. 397, no. 2, pp. 231-238, 1990.

[32] M. Moran, I. Cuadrado, J. R. Masaguer, J. Losada, C. FocesFoces, and F. H. Cano, "Cyclopentadienyl iron xanthate complexes. Crystal and molecular structure and electrochemical reduction of $\eta-\mathrm{C}_{5} \mathrm{R}_{5} \mathrm{Fe}(\mathrm{CO})_{2}\left(\eta^{1}-\mathrm{SC}(\mathrm{S}) \mathrm{OEt}\right)\left(\mathrm{R}=\mathrm{H}\right.$ or $\left.\mathrm{CH}_{3}\right)$," Inorganica Chimica Acta, vol. 143, no. 1, pp. 59-70, 1988.

[33] M. Moran, I. Cuadrado, C. Muñoz-Reja, J. R. Masaguer, and J. Losada, "Iron-xanthate complexes $\left[\mathrm{Fe}(\mathrm{CO})_{2}(\eta-\right.$ $\left.\left.\mathrm{C}_{5} \mathrm{R}_{5}\right)(\mathrm{SC}(\mathrm{S}) \mathrm{OEt})\right]$ and $\left[\mathrm{Fe}(\mathrm{CO})\left(\eta-\mathrm{C}_{5} \mathrm{R}_{5}\right)\left(\mathrm{S}_{2} \mathrm{COEt}\right)\right](\mathrm{R}=\mathrm{H}$ or $\mathrm{Me})$. Synthesis and electrochemistry," Journal of the Chemical Society, Dalton Transactions, no. 1, pp. 149-154, 1988.

[34] M. F. Hussain, R. K. Bansal, B. K. Puri, and M. Satake, "Trifluoroethylxanthate as a reagent for the determination of gold," The Analyst, vol. 109, no. 9, pp. 1151-1153, 1984.

[35] J. E. Drake, A. B. Sarkar, and M. L. Y. Wong, "Synthesis and characterization of $O$-methyl and $O$-ethyl dithiocarbonate (xanthate) derivatives of dimethyl- and diphenylgermane. Crystal structure of $\mathrm{Ph}_{2} \mathrm{Ge}\left[\mathrm{S}_{2} \mathrm{COMe}\right]_{2}$," Inorganic Chemistry, vol. 29, no. 4, pp. 785-788, 1990.

[36] J. P. Fackler Jr., H. W. Chen, and D. P. Schussler, "Sulfur chelates 29. $\mathrm{Ni}(\mathrm{II}), \mathrm{Pd}(\mathrm{II}), \mathrm{Pt}(\mathrm{II}), \mathrm{Co}(\mathrm{III})$ and $\mathrm{Cu}(\mathrm{I}, \mathrm{II})$ complexes of $O$ Phenyldithiocarbonates," Synthesis and Reactivity in Inorganic, Metal-Organic and Nano-Metal Chemistry, vol. 8, no. 1, pp. 2742, 1978.

[37] A. G. Roura, J. Casas, and A. Llebaria, "Synthesis and phospholipase C inhibitory activity of D609 diastereomers," Lipids, vol. 37, no. 4, pp. 401-406, 2002.

[38] J. N. Gaur, "Gravimetric determination of lanthanum, zirconium and thorium by ferrocyanide," Analytical \& Bioanalytical Chemistry, vol. 193, no. 2, pp. 86-89, 1963.

[39] U. N. Tripathi, P. P. Bipin, R. Mirza, and S. Shukla, "Synthesis and characterization of $O, O^{\prime}$ dialkyl and alkylene dithiophosphates of lanthanum(III) and their adducts with nitrogen and phosphorus donor bases," Journal of Coordination Chemistry, vol. 55, no. 10, pp. 1111-1118, 2002.

[40] R. K. Agarwal, R. K. Garg, and S. K. Sindhu, "Synthesis, spectral and thermal properties of some high coordinated complexes of thorium(IV) and dioxouranium(VI) derived from $4[\mathrm{~N}$ ( $2^{\prime}$ - hydroxy-1' -naphthalidene)amino] antipyrinethiosemicarbazone," Journal of the Iranian Chemical Society, vol. 2, no. 3, pp. 203-211, 2005.

[41] R. V. Singh, R. Dwivedi, and S. C. Joshi, "Synthetic, magnetic, spectral, antimicrobial and antifertility studies of dioxomolybdenum(VI) unsymmetrical imine complexes having a $N^{\mathrm{n}} N$ donor system," Transition Metal Chemistry, vol. 29, no. 1, pp. 7074, 2004.

[42] T. Imai, M. Nakamura, K. Nagai et al., "The synthesis, properties and molecular structures of the lanthanoid mixed complexes of $O, O^{\prime}$-diisoproply dithiophosphate and dimethyl 
sulfoxide: $\left[\mathrm{Ln}\left\{\left(\mathrm{C}_{3} \mathrm{H}_{7} \mathrm{O}\right)_{2} \mathrm{PS}_{2}\right\}_{3}\left\{\left(\mathrm{CH}_{3}\right)_{2} \mathrm{SO}\right\}_{2}\right]$ ( $\mathrm{Ln}=\mathrm{La}$ or $\left.\mathrm{Nb}\right)$, and $\left[\mathrm{Eu}\left\{\left(\mathrm{C}_{3} \mathrm{H}_{7} \mathrm{O}\right)_{2} \mathrm{PS}_{2}\right\}_{2}\left\{\left(\mathrm{CH}_{3}\right)_{2} \mathrm{SO}\right\}_{3}\right]\left[\mathrm{Eu}\left\{\left(\mathrm{C}_{3} \mathrm{H}_{7} \mathrm{O}\right\}_{2} \mathrm{PS}_{2}\right\}_{4}\right]$," Bulletin of the Chemical Society of Japan, vol. 59, no. 7, pp. 2115-2122, 1986.

[43] T. Imai, M. Shimoi, and A. Ouchi, "The structureof bis(dibenzyl sulfoxide)tris $\left(O, O^{\prime}\right.$-diethyl dithiophosphato)-lanthanum(III), $\mathrm{La}\left\{\left(\mathrm{C}_{2} \mathrm{H}_{5} \mathrm{O}\right)_{2} \mathrm{PS}_{2}\right\}_{3}\left\{\left(\mathrm{C}_{6} \mathrm{H}_{5} \mathrm{CH}_{2}\right)_{2} \mathrm{SO}\right\}_{2}$," Bulletin of the Chemical Society of Japan, vol. 59, no. 2, pp. 669-670, 1986.

[44] K. Nagai, Y. Sato, S. Kondo, and A. Ouchi, "The synthesis, properties and structure of bis( $N, N$-dimethylacetamide $)$-tris $\left(O, O^{\prime}\right.$ diisopropyl dithiophosphato)lanthanum(III)," Bulletin of the Chemical Society of Japan, vol. 56, no. 9, pp. 2605-2609, 1983.

[45] A. Syed and S. K. Pandey, "Syntheses, characterization, and biocidal aspects of $O, O^{\prime}$-ditolyl/dibenzyl dithiophosphates of lanthanum(III) and their adducts with nitrogen and phosphorus donor bases," Monatshefte für Chemie, vol. 144, no. 8, pp. 1129-1140, 2013. 

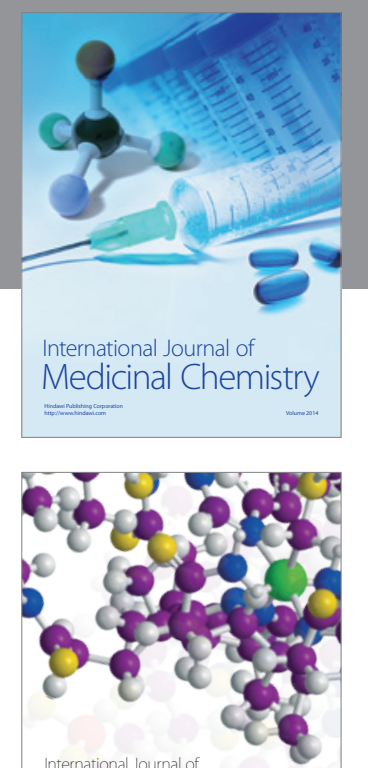

\section{Carbohydrate} Chemistry

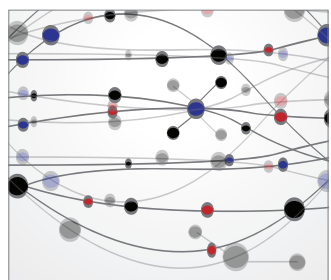

The Scientific World Journal
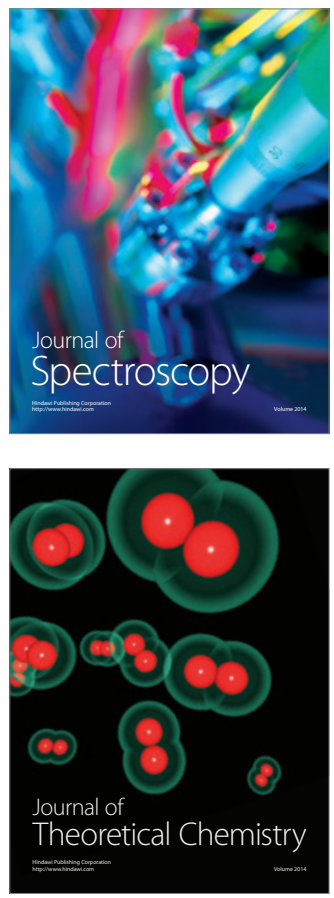
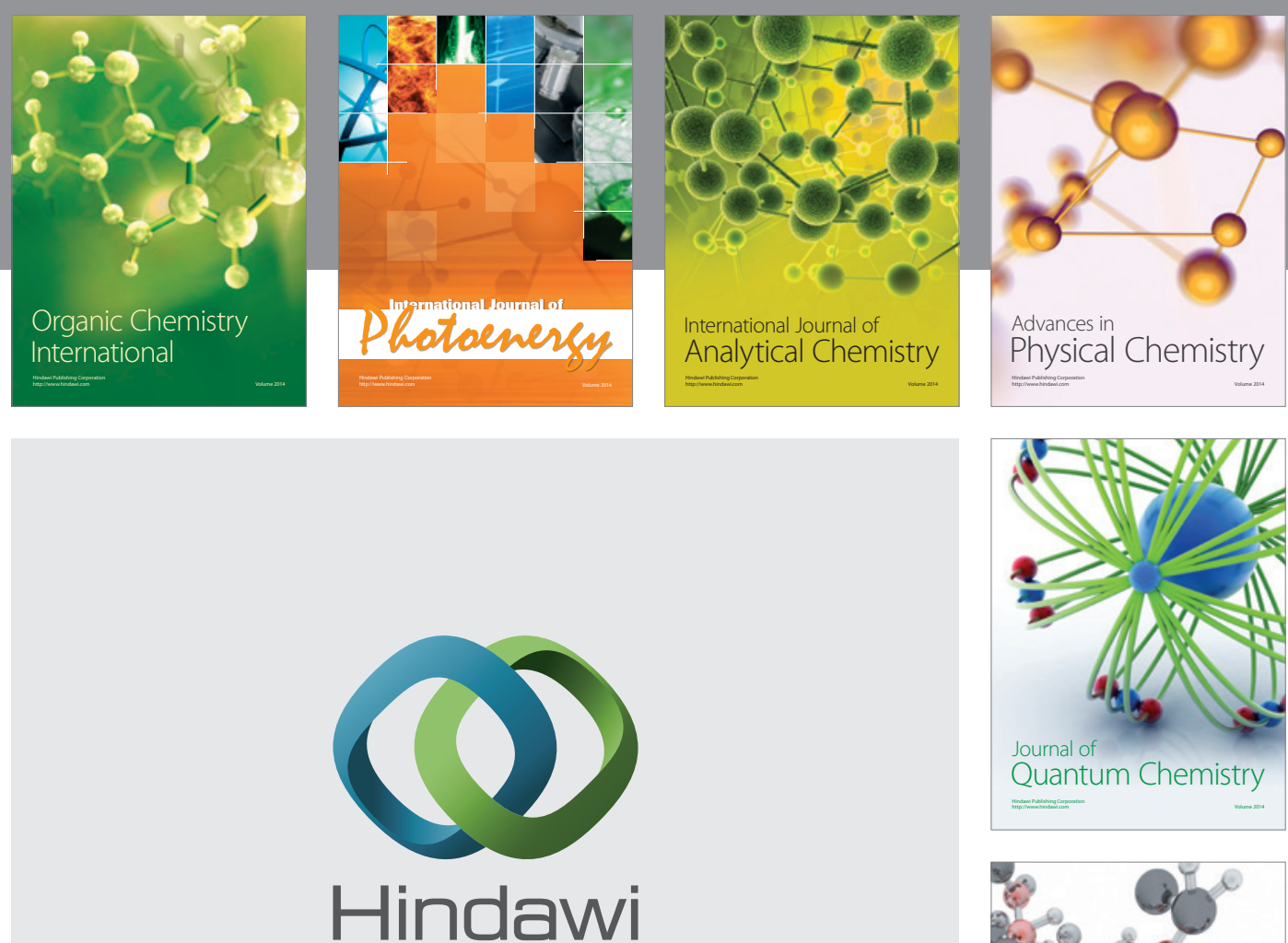

Submit your manuscripts at

http://www.hindawi.com

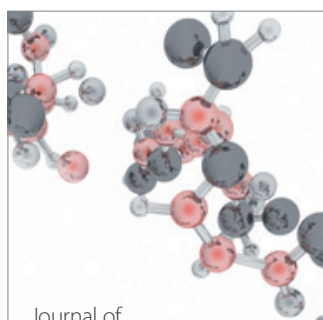

Analytical Methods

in Chemistry

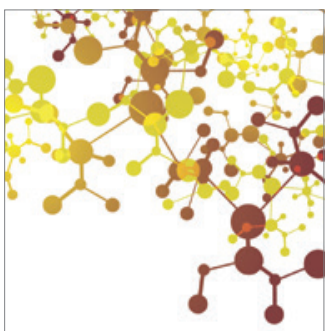

Journal of

Applied Chemistry

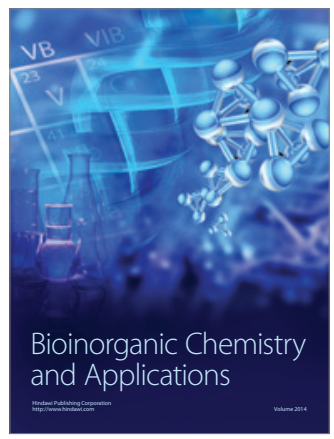

Inorganic Chemistry
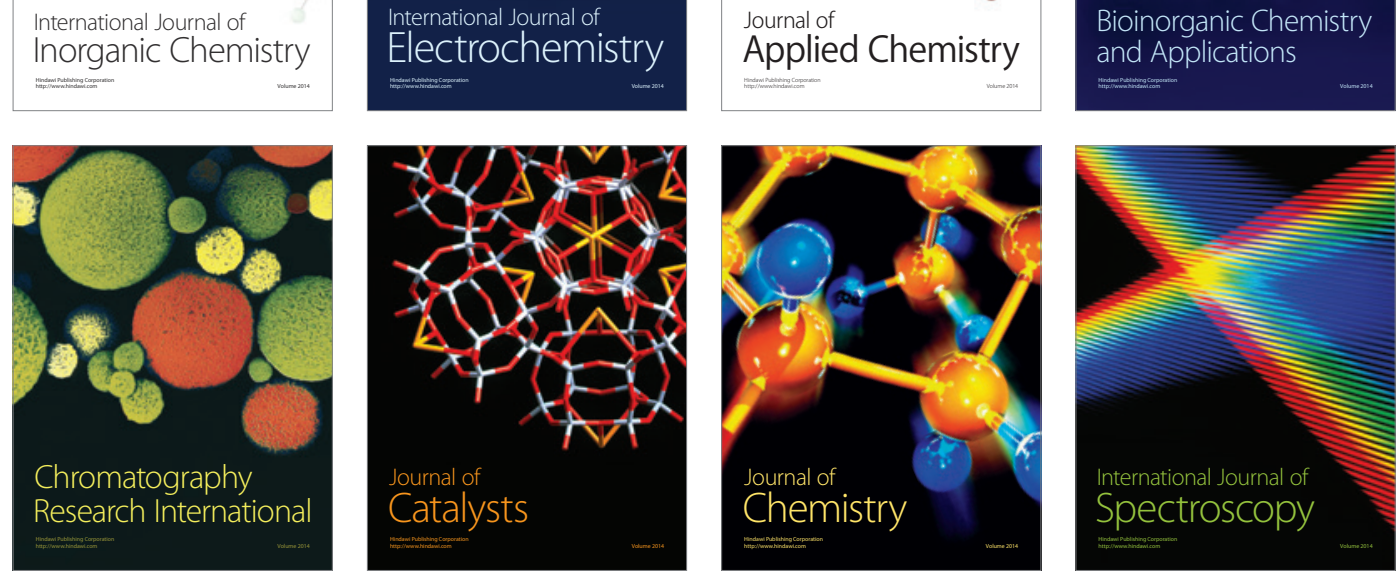